\title{
NOVEL SUBSTRATES TO MAINTAIN GUT INTEGRITY
}

\author{
KEITH R. GARDINER, STEPHEN J. KIRK AND BRIAN J. ROWLANDS \\ Department of Surgery, The Queen's University of Belfast, Institute of Clinical Science, \\ Grosvenor Road, Belfast BT12 6BJ, Northern Ireland, UK
}

\section{CONTENTS}

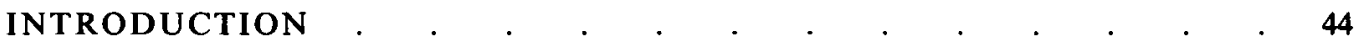

EVIDENCE FOR GUT MUCOSAL BARRIER DYSFUNCTION . . . . 44

CLINICAL SIGNIFICANCE OF GUT MUCOSAL BARRIER

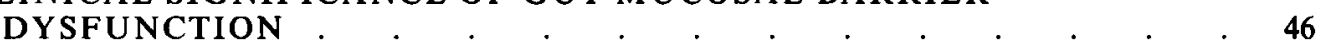

GUT DERIVED SEPSIS: THERAPEUTIC STRATEGIES. . . . . . 47

NOVEL SUBSTRATES AND GUT INTEGRITY . . . . . . . . . . 48

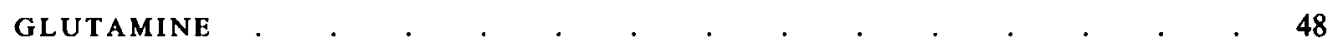

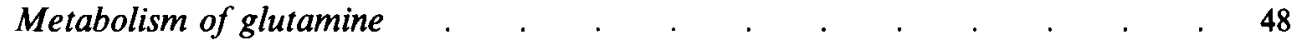

Glutamine and the gut mucosa . . . . . . . . . . . . . 48

Glutamine and experimental disease models . . . . . . . . . . . . . . . . 49

Glutamine supplemented TPN and experimental disease models . . . . . . 49

Glutamine supplemented enteral nutrition and experimental disease models . $\quad . \quad 49$

Rationale for clinical use of glutamine . . . . . . . . . . . . . . . . 50

Clinical use of glutamine . . . . . . . . . . . . . . . . . . . 51

ARGININE. . . . . . . . . . . . . . . . . . 51

Metabolism of arginine. . . . . . . . . . . . . . . . . . . 51

Arginine and the gut mucosa. . . . . . . . . . . . . . . . . . 51

Arginine and experimental disease models . . . . . . . . . . . 52

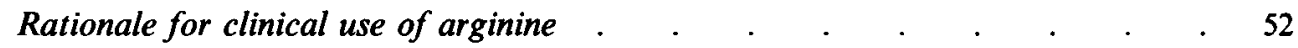

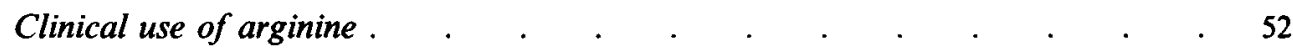

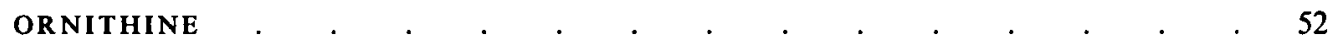

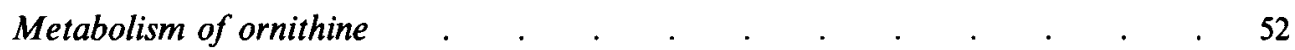

Ornithine and the gut mucosa . . . . . . . . . . . . . . . . 53

Ornithine and experimental disease models . . . . . . . . . . . . . 53

Rationale for the clinical use of ornithine . . . . . . . . . . . . . . . $\quad . \quad 53$

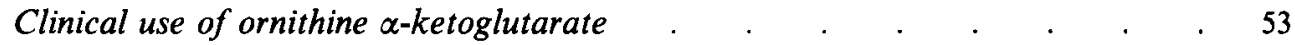

SHORT CHAIN FATTY ACIDS (SCFA) . . . . . . . . . . . . 53

Metabolism of SCFA . . . . . . . . . . . . . . . . . . . . 53

SCFA and the gut mucosa . . . . . . . . . . . . . . . . . . 53

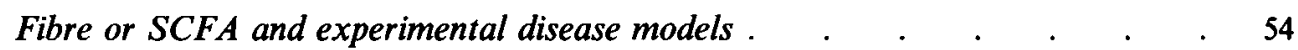

Rationale for the clinical use of SCFA . . . . . . . . . . . . . . . . . . $\quad . \quad 54$

Clinical use of SCFA 
$n$-3 POLYUNSATURATED FATtY ACIDS . . . . . . . . . . . 55

Metabolism of polyunsaturated fatty acids . . . . . . . . . . . . . . . . . 55

Eicosanoids and the gut mucosa . . . . . . . . . . . . . . . . 55

n-3 Polyunsaturated fatty acids and experimental disease models . . . . 55

Rationale for clinical use of n-3 polyunsaturated fatty acids . . . . . . $\quad$. 55

Clinical use of n-3 polyunsaturated fatty acids . . . . . . . . . . . . . . 55

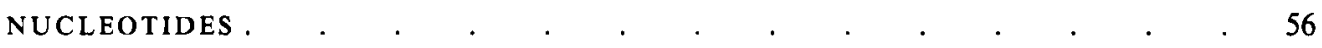

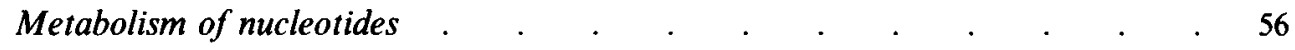

Nucleotides and the gut mucosa . . . . . . . . . . . . . . . . . . 56

Nucleotides and the gut flora. . . . . . . . . . . . . . . . . . 56

Nucleotides and experimental disease models . . . . . . . . . . . . . 56

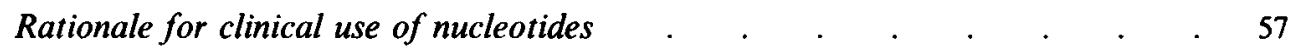

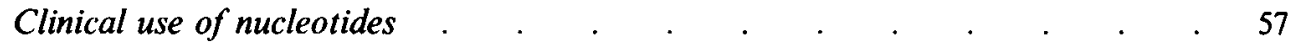

CONCLUSIONS. . . . . . . . . . . . . . . . . . . . 57

REFERENCES . . . . . . . . . . . . . . . . . . . 58

\section{INTRODUCTION}

Numerous scientific studies in the previous 20 years have documented the value of nutrient support in the management of patients with critical illness. In recent years there have been two major trends in the use of nutritional support. Primarily, there has been a major shift from intravenous towards enteral administration. Several large studies have established the advantages (reduced septic morbidity, and reduced cost) of early enteral (compared to parenteral) feeding. Secondly, there have been major changes in the content and protein/calorie mix of the formulations used. The most striking findings relate to the use of specific nutrient substrates to supplement standard enteral diets. Glutamine, arginine, branched chain amino acids, $n-3$ fatty acids, ornithine and nucleotides have attracted most attention. They produce their beneficial effects in several ways: support of the systemic immune response, enhancement of gut mucosal barrier function, modulation of the neuroendocrine and cytokine responses and of Kupffer cell function.

This article will critically review the use of novel substrates which have a perceived role in the maintenance of gut integrity. We will assess their roles in health and disease, the rationale for their clinical use, their mechanism of action and supporting evidence from clinical and animal studies of their efficacy.

The intestinal tract is usually thought of primarily as a digestive and absorptive organ. However, it also has a major barrier function, protecting the body from potentially harmful intraluminal pathogens and large antigenic molecules (Saadia et al. 1990), and additionally plays a pivotal role in the metabolic processing of glutamine (Souba et al. 1985). The gut mucosal barrier comprises both non-immunological and immunological components (Langkamp-Henken et al. 1992; Table 1). Normal epithelial cell structure prevents transepithelial migration of particles from the gut lumen, and tight junctions between cells prevent movements through the paracellular channels (van Leeuwen et al. 1994).

\section{EVIDENCE FOR GUT MUCOSAL BARRIER DYSFUNCTION}

Many studies investigating the intestinal barrier have examined nutritionally induced changes in intestinal weight or structure (villous height, crypt depth) or mucosal content of protein or DNA as indicators of intestinal atrophy. The demonstration of intestinal atrophy 
Table 1. Components of the gut mucosal barrier

\begin{tabular}{ll}
\hline \multicolumn{1}{c}{ Non-immunological } & \multicolumn{1}{c}{ Immunological } \\
\hline Salivary secretions (lactoferrin, lysozyme) & $\begin{array}{l}\text { Gut-associated lymphoid tissue } \\
\text { Intraluminal gastric pH }\end{array}$ \\
Proteolysis & \\
Intestinal bile salts & \\
Peristalsis & \\
Mucus coat & \\
Microvillus membrane & \\
Commensal bacteria & \\
\hline
\end{tabular}

has often been assumed to indicate impaired intestinal barrier function. However, animal studies of prolonged protein malnutrition have shown no direct correlation between the development of intestinal atrophy and the loss of barrier function (Deitch et al. 1990a).

Dysfunction of the mucosal barrier is thought to result from an imbalance of aggressive and defensive factors acting on the gastrointestinal mucosa (Sartor, 1990). Genetic and environmental factors may modify the response of the gastrointestinal mucosa to proinflammatory factors or may modify the protective factors. Increased gastric acid production, colonization with Helicobacter pylori, ingestion of non-steroidal antiinflammatory analgesics and the use of broad spectrum antibiotics predispose the gastrointestinal mucosa to ulceration (Berg, 1981). Mucosal blood flow (Fink, 1991), oxidative fuel supply (van der Hulst et al. 1993) and a normal intestinal bacterial flora (Barber et al. 1991) protect against barrier dysfunction.

Failure of the intestinal mucosal barrier results in permeation of microbial and dietary antigens across the intestinal wall. The transmural migration of enteric bacteria or bacterial endotoxins to extraintestinal sites has been termed translocation (Berg \& Garlington, 1979; van Leeuwen et al. 1994). Bacterial translocation is assessed by quantitative and qualitative culture of samples of blood, mesenteric lymph nodes, liver and spleen or by the detection of radioactivity in extraintestinal tissues following the oral administration of bacteria labelled with ${ }^{14} \mathrm{C}$ or fluorescein isothiocyanate (FITC). Translocation of endotoxin into the portal or systemic circulation can be assessed using the chromogenic Limulus assay or by measurement of plasma radioactivity after administration of labelled $\left[{ }^{3} \mathrm{H}\right]-,\left[{ }^{125} \mathrm{I}\right]-$ or $\left[{ }^{14} \mathrm{C}\right]$ endotoxin. There is growing evidence from both in vivo (Alexander et al. 1990; Wells et al. 1990) and in vitro (Wells et al. 1993; Cruz et al. 1994; Go et al. 1995) studies that transmucosal passage of intestinal organisms occurs transcellularly.

The term 'permeability' is used to describe the passive penetration of the intestinal barrier by non-charged and usually non-absorbable macromolecules (Travis \& Menzies, 1992). An increase in the permeability of the intestinal wall to macromolecules in comparison to normal intestine is thought to result from migration through the junctional complex (paracellular route), through ulcerations or across extrusion zones at the villous tip. The degree of intestinal permeability is usually assessed by measuring the urinary excretion of orally administered non-metabolized macromolecules such as sugars (lactulose, mannitol, rhamnose, cellobiose), inert polymers (polyethylene glycol, FITC-dextran) or radiolabelled compounds $\left({ }^{51} \mathrm{Cr}\right] \mathrm{EDTA}, \quad\left[{ }^{99 \mathrm{~m}} \mathrm{Tc}\right]$ diethylenetriaminepenta-acetic acid (DTPA); Travis \& Menzies 1992).

The evidence that bacterial translocation occurs transcellularly and that permeability is related to molecular penetration of the tight junction suggests that these measures of barrier function may be unrelated. Indeed, bacterial translocation is a much more complex 
phenomenon than permeability, depending on intestinal resistance to bacterial adherence and the gut-associated lymphoid tissue, in addition to the mechanical barrier of the intestinal mucosa (Deitch, $1990 \mathrm{a}$ ). Thus increased translocation reflects a failure of one or more components of the mucosal defense system and not necessarily damage to the epithelial barrier per se (Fink, 1991).

However, increases in both permeability and translocation have been observed in animal models of gut atrophy induced by elemental diets, lack of dietary fibre or total parenteral nutrition (TPN), sepsis and haemorrhagic shock (Deitch et al. 1990 b, 1991, 1995; Spaeth et al. 1994). Rats that are nourished by TPN alone develop progressive gut atrophy with loss of mucosal thickness and villous height (Levine et al. 1974; Koga et al. 1975; Eastwood, 1977), a significant increase in intestinal permeability to lactulose within $48 \mathrm{~h}$ (Helton et al. 1991) and translocation of enteric bacteria after 7-10 d (Alverdy et al. 1990). In contrast, Illig et al. (1992) did not find any correlation between intestinal permeability to lactulose and translocation of bacteria in TPN induced intestinal atrophy.

\section{CLINICAL SIGNIFICANCE OF GUT MUCOSAL BARRIER DYSFUNCTION}

Enhanced uptake of macromolecules and bacteria has been demonstrated where the intestinal mucosa is damaged by inflammation (Gardiner et al. 1995), infection (BrockUtne \& Gaffin, 1989), neoplasia (Lescut et al. 1990) or trauma (Kelley et al. 1985). In addition, systemic endotoxaemia, bacterial translocation and increased intestinal permeability to macromolecules have been demonstrated in patients with rheumatic diseases (Busch et al. 1988), haemorrhagic shock (Roumen et al. 1993), burns (Deitch, 1990b; LeVoyer et al. 1992), burn sepsis (Ziegler et al. 1988), major trauma (Rush et al. 1988; Roumen et al. 1993), following chemotherapy or radiotherapy (Parrilli et al. 1982), and in experimental endotoxaemia in human volunteers (O'Dwyer et al. 1988) in the absence of macroscopic intestinal disease. However, translocation of endotoxin or bacteria have not been commonly found in patients after major trauma (Rush et al. 1988; Moore et al. 1991; Hoch et al. 1993; Roumen et al. 1993) or burns (Deitch, 1990 b).

The clinical significance of intestinal mucosal barrier dysfunction is more difficult to determine. In patients with inflammatory bowel disease, translocation of endotoxin and bacteria may explain systemic immune activation, disturbances in hepatic function, the pathogenesis of abscesses and fistulas, extraintestinal manifestations, and the high incidence of sepsis following elective surgery (Eade \& Brooke, 1969; Ambrose et al. 1984; Wellmann et al. 1986). Evidence to support this hypothesis comes from studies demonstrating positive correlations between clinical and laboratory measures of disease activity and intestinal permeability to hydrophilic probes $\left[{ }^{51} \mathrm{Cr}\right] \mathrm{EDTA}$ and $\left[{ }^{99 \mathrm{~m}} \mathrm{Tc}\right] \mathrm{DTPA}$ (Murphy et al. 1989; Pironi et al. 1990) and systemic endotoxin concentrations (Wellmann et al. 1986; Gardiner et al. 1995) in both ulcerative colitis and Crohn's disease. In addition, the incidence of positive portal blood cultures in patients with ulcerative colitis submitted to colectomy was found to be associated with disease severity (Eade \& Brooke, 1969).

In patients with intestinal obstruction, a significantly higher incidence of septic complications was seen in those with bacterial translocation $(28 \%)$ compared with those without (11\%), but mortality was unaffected (Sedman et al. 1994). However, the organisms cultured from the operative samples rarely correlated with those causing postoperative sepsis. There are two possible explanations: either septic complications were causally related to bacterial translocation, or both the septic complications and bacterial translocation were separate manifestations of impaired immunity (Sedman et al. 1994). 
In critically ill patients, there is circumstantial evidence linking intestinal barrier failure to the hypermetabolic response and multiple organ system failure associated with major trauma, burns and sepsis (Carrico et al. 1986; Saito et al. 1987a; Wilmore et al. 1988; Saadia et al. 1990). Infections acquired by intensive care patients were found to be similar to bacterial cultures from the proximal gastrointestinal tract (Marshall et al. 1988). Enteric microorganisms were responsible for the majority of infective complications in a group of 206 critically ill trauma patients (Tran et al. 1993). Enteric organisms have also been demonstrated in the peripheral blood in patients who are immunocompromised (Tancrede \& Andremont, 1985) or traumatized (Rush et al. 1988). In the leukaemic patients, Gramnegative bacteraemia was due to the dominant faecal strain of Enterobacteriaceae or Pseudomonas aeruginosa in $82 \%$ of episodes (Tancrede \& Andremont, 1985). More direct evidence was provided by Ziegler et al. (1988) who found that an increase in intestinal permeability to lactulose was associated with infection in burn patients. LeVoyer et al. (1992) were able to go further by establishing a positive correlation between intestinal permeability to lactulose and the later development of septic complications in patients with burns. In addition, Oudemans found a clear relation between translocation of endotoxin from the gut and postperfusion syndrome in patients having cardiopulmonary bypass (van Leeuwen et al. 1994).

Clinical studies have therefore shown that intestinal barrier dysfunction is a frequent occurrence in patients with intestinal inflammation or obstruction and can also occur during critical illness. Against this background, it has been hypothesized that translocating endotoxin and bacteria activate a systemic inflammatory cascade and promote multiple organ dysfunction. However, more evidence is required before a direct causal link can be established (Sedman et al. 1994).

\section{GUT DERIVED SEPSIS: THERAPEUTIC STRATEGIES}

Maintenance of intestinal epithelial cell structure, balanced luminal microbial populations and gut associated lymphatic tissue have all been considered necessary to prevent translocation of bacteria and toxins from the intestinal lumen to the bloodstream and other organs (Deitch 1991). On this basis, several strategies have been devised to prevent gut origin septic complications in critically ill patients (Table 2).

A wide variety of antibiotics has been successfully used to suppress the faecal Gramnegative aerobic bacilli in healthy volunteers, immunosuppressed patients, critically ill patients and experimental animals (Dekker et al. 1981; Edlund et al. 1987; RozenbergArska \& Dekker, 1987). Modification of the intestinal flora is associated with a decreased incidence of complicating infections, including Gram-negative bacteria in various organs and also a decrease in Gram-negative bacteraemia (Dekker $e t$ al. 1981 ; Rozenberg-Arska \& Dekker, 1987; Blair et al. 1991).

Enteral diet, in comparison with TPN was found to reduce septic complications, improve nutritional status and improve survival in burned children, injured adults, intensive care unit patients and animals with experimental haemorrhagic shock (Alexander et al. 1980; Border et al. 1987; Moore et al. 1989; Zaloga et al. 1991; Kudsk 1994). In addition to the route of administration, the composition of the enteral diet is also important. Polymeric enteral diets are superior to liquid elemental diets in preventing atrophy of the intestinal mucosa, maintaining mucosal protein and DNA content, secretory immunoglobulin A production, a normal balance of intestinal microflora and mucosal barrier function (Alverdy et al. 1990; Barber et al. 1990; Shou et al. 1991; Deitch et al. 1993, 1995; Spaeth et al. 1994). 
Table 2. Strategies to prevent gut origin sepsis

\begin{tabular}{ll}
\hline Strategy & Method \\
\hline Selective digestive decontamination & $\begin{array}{l}\text { Use of antibiotics to eliminate target } \\
\text { organisms (enteric Gram-negative bacilli and } \\
\text { fungi) without affecting non-pathogenic } \\
\text { organisms }\end{array}$ \\
Immunomodulation & $\begin{array}{l}\text { Administration of substrates (arginine, } \\
\text { nucleotides, } n \text {-3 fatty acids) to enhance the } \\
\text { immune response to bacteria }\end{array}$ \\
$\begin{array}{c}\text { Mucosal enhancement therapy } \\
\text { (a) Enteral nutrition } \\
\text { (b) Selective intestinal nutrients } \\
\text { (Deitch 1991) }\end{array}$ & $\begin{array}{l}\text { Promotion of intestinal epithelial cell } \\
\text { proliferation, differentiation and } \\
\text { function }\end{array}$ \\
(c) Growth factors (Jacobs et al. 1988) & \\
(d) Trophic gut hormones & \\
(Evers et al. 1990) &
\end{tabular}

\section{NOVEL SUBSTRATES AND GUT INTEGRITY}

Several strategies combining early nutrition and eradication of bacteria/endotoxin have been suggested for preventing gut failure and subsequent sepsis syndrome or multiple organ failure. However, there has been considerable interest in the utilization of specific substrates (selective gut nutrition) to maintain intestinal mucosal integrity as a barrier to bacteria and endotoxin (Deitch 1991; Elsen \& Bistrian, 1991). Substrates suggested as capable of maintaining intestinal integrity include amino acids (glutamine, arginine and ornithine), fatty acids (short chain and $n-3$ polyunsaturated) and nucleotides.

\section{GLUTAMINE}

Glutamine is a neutral amino acid which is obtained directly from the diet or indirectly by conversion from $\alpha$-ketoglutarate or transamination of other amino acids. Glutamine was originally classified as non-essential but is now considered to be conditionally essential in many pathological states (Wilmore et al. 1988; Souba et al. 1990a).

\section{Metabolism of glutamine}

Glutamine is actively transported across the intestinal brush border by system B transporters (Souba \& Copeland, 1992). Glutamine is metabolized in the urea cycle, protein synthetic pathways and the Krebs cycle for energy and for production of citrate, lactate and glucose. It acts as a vehicle for nitrogen transfer between tissues, as a substrate for renal ammoniagenesis and as a precursor for nucleotides. Glutamine is important in the regulation of glycogen synthesis and protein turnover (Smith \& Wilmore, 1990). It is also an important metabolic substrate for enterocytes, lymphocytes and many cell culture systems (Smith \& Wilmore, 1990).

\section{Glutamine and the gut mucosa}

Glutamine is the principal respiratory fuel of the small intestine (Windmueller 1982; Souba et al. 1985) and also provides a major portion of the energy required by colonocytes (Ardawi \& Newsholme, 1985). It stimulates protein synthesis in isolated enterocytes (Higashiguchi et al. 1993) and is essential for the proliferation and differentiation of 
enterocytes (Beaulieu \& Calvert 1985). Supplementation of standard chow with glutamine increased blood flow to stomach, small intestine and colon in healthy rats (Houdijk et al. 1994). Intestinal uptake of glutamine from both the intestinal lumen and mesenteric circulation falls during sepsis and endotoxaemia (Souba et al. 1990 b; Salloum et al. 1991). It has been suggested that this impairment in gut glutamine uptake may result in ultrastructural changes in the small intestine and failure of the gut mucosal barrier (Wilmore et al. 1988).

\section{Glutamine and experimental disease models}

Experimental glutamine deficiency results in diarrhoea, villous atrophy, mucosal ulceration and intestinal necrosis (Baskerville et al. 1980). As the administration of either TPN or of an elemental diet as the sole energy source is associated with intestinal mucosal atrophy and barrier dysfunction, the effects of glutamine supplementation will be considered in these two situations. The effects of supplementation with novel substrates will be evaluated under four headings: $(a)$ intestinal morphology (mucosal thickness and villus height); $(b)$ biochemical parameters (mucosal protein and DNA content); $(c)$ function (digestion, absorption, metabolic activity, barrier function); and (d) outcome.

\section{Glutamine supplemented TPN and experimental disease models}

In starvation-induced gut atrophy (Inoue et al. 1993 b), glutamine supplementation (a) improved intestinal morphology; and (c) increased mucosal activity of sucrase (EC 3.2.1.48) and maltase (EC 3.2.1.20).

In a model of short bowel syndrome (Wang et al. 1988; Jiang et al. 1993), glutamine supplementation (a) improved intestinal morphology.

In TPN induced gut atrophy (Grant \& Snyder, 1988; Jacobs et al. 1988; Burke et al. 1989; O'Dwyer et al. 1989; Tamada et al. 1992; Jiang et al. 1993; Platell et al. 1993; Burrin et al. 1994; Li et al. 1994), provision of glutamine as either a free amino acid or in dipeptide form (a) improved small and large intestinal morphology (exceptions-jejunal (Babst et al. 1993; Spaeth et al. 1993); colonic (Platell et al 1993)); (b) increased mucosal DNA and protein contents (exception-Burrin et al. 1994); and (c) increased mucosal enzyme activity, decreased bacterial translocation (exception-Spaeth et al. 1993) and prevented an increase in intestinal permeability (Li et al. 1994).

In a small bowel transplantation model (Frankel et al. 1993), supplemental glutamine (a) improved intestinal morphology; and (c) improved intestinal monosaccharide absorption.

In experimental sepsis (Ardawi, 1991; Yoshida et al. 1992; Inoue et al. 1993 a; Kaneko et al. 1993; Chen et al. 1994), supplemental glutamine (a) improved intestinal morphology; (b) increased intestinal mucosal protein content; $(c)$ increased mucosal glutaminase (EC 3.5.1.2) activity and reduced bacterial translocation; and $(d)$ improved survival.

In a rat abdominal radiation model (Scott \& Moellman, 1992), glutamine supplementation had no effect on $(a)$ intestinal morphology; and $(b)$ mucosal DNA content.

\section{Glutamine supplemented enteral nutrition and experimental disease models}

In experimental haemorrhagic shock, suffusion of the small intestinal mucosa with isotonic glutamine attenuated the shock induced impairment in intestinal blood flow (Flynn et al. 1992). Bark et al. (1995) reported that in a rat model of non-lethal haemorrhage a glutamine-supplemented enteral diet (c) had no effect on bacterial translocation.

Pretreatment with oral glutamine decreased the severity of aspirin induced gastric ulcerations (Okabe et al. 1975). 
In starvation induced gut atrophy (Salloum et al. 1989), a glutamine supplemented elemental diet $(a)$ improved intestinal morphology; and $(c)$ increased mucosal glutaminase activity and decreased bacterial translocation.

In elemental diet induced gut atrophy (Barber et al. 1990; Deitch et al. 1993; Wusteman et al. 1995), supplemental glutamine (a) improved intestinal morphology; (b) increased mucosal protein content; and $(c)$ had no effect on bacterial translocation. However, rats given Vivonex TEN, which has a high content of free glutamine, had decreased bacterial translocation compared with two other elemental diets (Alverdy et al. 1990).

In a cyclosporin treated model of small bowel transplantation in rats (Zhang et al. 1995), supplemental glutamine $(a)$ improved intestinal morphology; and (c) reduced bacterial translocation.

In experimental sepsis (endotoxaemia), glutamine supplementation of an elemental diet (c) had no effect on bacterial translocation; and (d) had no effect on survival (Barber $e t$ al. 1990).

Prophylactic enrichment of an elemental diet with glutamine protected the gut mucosa from radiation injury (Klimberg et al. 1990b) by (a) improving intestinal morphology; but $(b)$ had no effect on mucosal DNA or protein content; and $(c)$ had no significant effect on bacterial translocation.

In radiation induced enterocolitis (Klimberg et al. 1990 a; Souba et al. 1990 c; Karatzas et al. 1991; Jensen et al. 1994), supplemental glutamine (a) diminished bloody diarrhoea and the incidence of bowel perforation, and improved intestinal morphology; (c) increased intestinal glutaminase activity and decreased systemic endotoxaemia and bacterial translocation; and $(d)$ improved survival.

In a study on experimental colonic anastomoses (McCauley et al. 1991), supplemental glutamine had no effect on colonic healing.

In a mouse burn model (Gianotti et al. 1995), glutamine supplementation (c) reduced bacterial translocation; and $(d)$ increased survival.

In a rat methotrexate treated sarcoma model (Klimberg et al. 1992), supplemental glutamine $(b)$ increased jejunal DNA content; $(c)$ reduced bacteraemia; and $(d)$ reduced mortality.

In chemotherapy induced enterocolitis (Jacobs et al. 1987; O'Dwyer et al. 1987; Fox et $a l .1988 a, b$; Shou et al. 1991), supplemental glutamine (a) promoted repair of intestinal mucosa; $(b)$ increased jejunal and colonic mucosal protein and DNA content; $(c)$ decreased bacterial translocation (exception Shou et al. 1991) and decreased systemic endotoxaemia; and (d) increased survival (exception Shou et al. 1991).

In summary, glutamine supplementation of TPN or of elemental enteral nutrition improves intestinal structure, function and outcome in most of these experimental models. However, two important points should be remembered. Firstly, while TPN administration is associated with intestinal atrophy and bacterial translocation in the rat, there is no evidence of intestinal atrophy on TPN either in the mouse (Sitren et al. 1992) or in humans (Guedon et al. 1986) and no increased incidence of TPN induced bacterial translocation in patients (Sedman et al. 1993). Secondly, while glutamine supplementation of elemental nutrition was beneficial in these models, a normal or polypeptide diet was well tolerated and even more beneficial in the chemotherapy induced enterocolitis models (Harvey et al. 1987; Shou et al. 1991).

\section{Rationale for clinical use of glutamine}

Stress, surgery and sepsis result in an increased demand for glutamine as a substrate by enterocytes both as a fuel and as a precursor for purines, pyrimidines and other nitrogencontaining compounds (Souba et al. 1990a). Increased glutamine demand without 
increased supply will result in efflux of glutamine from skeletal muscle and may lead to structural and functional intestinal disturbances (Souba et al. $1990 \mathrm{a}$ ). Exogenous supply of glutamine or glutamine-containing dipeptides may therefore be beneficial to the intestinal mucosa in patients with injury and infection by stimulating enterocyte metabolism and maintaining intestinal mucosal integrity, thereby reducing bacterial translocation.

\section{Clinical use of glutamine}

In pre-operative patients with inflammatory bowel disease or cancer (van der Hulst $e t$ al. 1993), glutamine supplemented TPN (a) preserved duodenal mucosal morphology; and (c) prevented deterioration in intestinal permeability.

In the critically ill (Tremel et al. 1994) and in those with short bowel syndrome (Byrne et al. 1992), glutamine supplemented TPN (c) improved intestinal absorption of nutrients.

In patients undergoing bone marrow transplantation, glutamine supplemented TPN $(c)$ reduced microbial colonization (Ziegler et al. 1992); and (d) reduced length of hospital stay (Schloerb \& Amare, 1993).

In premature infants (Wilmore, 1994), glutamine supplemented TPN $(d)$ reduced length of time on mechanical ventilation and on TPN.

Glutamine supplemented TPN had no effect on gastrointestinal toxicity in patients undergoing chemotherapy for haematological malignancies (van Zaanen et al. 1994).

Taken together, these studies suggest that glutamine supplementation of TPN is superior to standard TPN in the maintenance of intestinal structure and function in patients (Wilmore, 1994). There is also some evidence that these benefits translate into reduced hospital costs (MacBurney et al. 1994).

\section{ARGININE}

Arginine is a dibasic amino acid which the body obtains from dietary sources and by endogenous synthesis via the urea cycle. Arginine is essential for growth in cats, conditionally essential in mice and rats but non-essential in man (Grimble, 1993). There is evidence that arginine becomes indispensable for adequate nitrogen balance under severe stress due to sepsis, trauma or nitrogen overload (Kirk \& Barbul, 1990; Gonce et al. 1990).

\section{Metabolism of arginine}

Arginine is absorbed by the small intestine by active transport system $\mathbf{y}^{+}$. Both the liver and the kidney can synthesize arginine from citrulline and ornithine via the urea cycle (Barbul, 1986). Arginine is a precursor of polyamine, histone and nucleic acid synthesis, is a promoter of thymic growth and is an endocrinological secretagogue stimulating release of prolactin, insulin and glucagon (Barbul, 1986).

\section{Arginine and the gut mucosa}

Arginine is metabolized within the enterocyte via the arginase (EC 3.5.3.1) pathway to ornithine and urea and via the arginine deiminase (EC 3.5.3.6) pathway to citrulline and nitric oxide (Blachier et al. 1991). Arginine metabolism in the gut protects this amino acid from excessive degradation in the liver (Cynober, 1994). In addition, arginine metabolism in enterocytes may participate in the support of gut morphology and function by acting as a substrate for nitric oxide synthesis (Cynober, 1994). Inhibition of nitric oxide synthesis increased intestinal mucosal permeability in experimental models of ischaemia-reperfusion intestinal injury in the cat (Kubes, 1993) and acute necrotizing enterocolitis in the rabbit (Miller et al. 1993 b). In addition, administration of L-arginine reversed the effect of nitric oxide synthase inhibition (Kubes, 1993). These results suggest that basal nitric oxide production is important in minimizing the mucosal barrier dysfunction in these models. 


\section{Arginine and experimental disease models}

In experimental colitis (Neilly et al. 1993), supplemental enteral arginine (a) increased mucosal inflammation, whereas administration of nitric oxide synthase inhibitors reduced intestinal inflammation in rat colitis and rabbit ileitis models (Miller et al. $1993 a$; Neilly et al. 1995).

In an experimental burn model (Saito et al. 1987b, Gianotti et al. 1993), supplemental enteral arginine $(c)$ reduced bacterial translocation; and $(d)$ improved survival.

In experimental sepsis, supplemental arginine $(d)$ improved survival in mouse (Gianotti et al. 1993) and rat (Madden et al. 1988) models but not in a guineapig model (Gonce et al. 1990).

\section{Rationale for clinical use of arginine}

As a result of its actions as a precursor of polyamine synthesis and protein synthesis and as a secretagogue, it has been suggested that arginine might be a substrate capable of supporting gut function (Gianotti et al. 1993; Cynober 1994).

However, a large fraction of metabolized arginine is transported out of the enterocyte as ornithine and citrulline, suggesting that arginine metabolism may not be responsible for substantial intestinal polyamine synthesis. The experimental studies reviewed above provide conflicting evidence on the effects of arginine on gut structure, function or outcome. Enhancement of immune rather than gut function may explain the arginine induced exacerbation of experimental colitis (Neilly et al. 1995) as well as the beneficial effects of arginine on bacterial translocation and survival in the experimental burn model (Gianotti et al. 1993). In addition, the role of arginine as a substrate for nitric oxide synthesis and the observations implicating nitric oxide in the pathogenesis of septic shock syndrome (Petros et al. 1991) suggest that excess arginine supplementation could be potentially hazardous in severely ill patients (Cynober, 1994).

\section{Clinical use of arginine}

In combination with nucleotides and $n-3$ polyunsaturated fatty acids, arginine (Impact) has been administered to patients with gastrointestinal cancer and critical illness (Cerra et al. 1990; Daly et al. 1992, 1995; Bower et al. 1995). No effect on intestinal morphology, biochemical parameters or function has been reported. Patients administered this triple therapy had reduced infectious and wound complications and reduced length of hospital stay. It is probable that the observed beneficial effects of these substrates were due to improved function of the immune system rather than improved gut barrier function.

\section{ORNITHINE}

Ornithine is a non-essential basic amino acid obtained from the diet or by synthesis from arginine via the urea cycle. It is not a constituent of proteins but is a precursor of aliphatic polyamines and an endocrinological secretagogue (Cynober, 1994). In addition, in the form of the $\alpha$-ketoglutarate salt, ornithine generates glutamine which plays a key part in the control of protein metabolism (Cynober et al. 1990). Ornithine has also been shown to increase nitrogen retention, and to improve wound healing and thymic function in experimental animals (Barbul, 1986).

\section{Metabolism of ornithine}

Ornithine shares an active transport system $\left(\mathrm{y}^{+}\right)$in the small intestine with arginine. Ornithine is metabolized to citrulline via the ornithine carbamoyltransferase (EC 2.1.3.3) pathway, to glutamate and proline via the ornithine aminotransferase (EC 2.6.1.13) 
pathway and to putrescine, spermidine and spermine via the ornithine decarboxylase (EC 4.1.1.17) pathway (Cynober, 1994).

Ornithine and the gut mucosa

Enterocytes possess ornithine decarboxylase, ornithine carbamoyltransferase and ornithine aminotransferase (Cynober, 1994). However, after enteral administration of $\left[{ }^{14} \mathrm{C}\right]$ ornithine, only $\left[{ }^{14} \mathrm{C}\right]$ proline, $\left[{ }^{14} \mathrm{C}\right]$ glutamate and $\left[{ }^{14} \mathrm{C}\right]$ polyamines are detected (Vaubourdolle et al. 1989). It has been suggested that ornithine metabolism in enterocytes, by acting as a precursor for polyamine synthesis, may support gut morphology (Cynober, 1994).

Ornithine and experimental disease models

In a rat starvation model (Cynober, 1994) supplementation with ornithine $\alpha$ ketoglutarate $(a)$ increased intestinal crypt and villous height; and $(c)$ increased brush border enzyme content.

\section{Rationale for the clinical use of ornithine}

As with arginine, ornithine is a precursor of polyamine synthesis and an endocrinological secretagogue and might therefore be important in supporting gut function (Cynober, 1994). There is one experimental study, described above, to support this hypothesis (Cynober, 1994).

\section{Clinical use of ornithine $\alpha$-ketoglutarate}

As with glutamine, supplemental ornithine $\alpha$-ketoglutarate improved nitrogen balance and prevented reduction in muscle free glutamine in patients undergoing elective surgery (Stehle et al. 1989; Hammarqvist et al. 1990). The mode of action of ornithine $\alpha$ ketoglutarate in the prevention of skeletal muscle breakdown is probably as a precursor of glutamine. A direct beneficial clinical effect of ornithine or ornithine $\alpha$-ketoglutarate on gut structure, function or outcome has not yet been shown in clinical studies.

\section{SHORT CHAIN FATTY ACIDS (SCFA)}

SCFA (acetic, propionic and butyric acids) are among the major anions in colonic contents. They are found to a limited extent in the diet but are primarily produced in the proximal colon by anaerobic bacterial fermentation of dietary carbohydrates such as pectin (Cummings \& Branch, 1986).

\section{Metabolism of SCFA}

SCFA are rapidly absorbed in the colon, mostly by non-ionic transcellular diffusion (Scheppach, 1994), and metabolized within the colonocyte via a $\beta$-oxidation pathway requiring the presence of coenzyme $A$, to produce energy (D'Argenio et al. 1994). Apart from the colonic mucosa, the liver is the main site of SCFA metabolism (Rémésy et al. 1980 ; Koruda et al. 1990; Scheppach, 1994). Acetate is also used as a fuel source by skeletal and cardiac muscle (Scheppach et al. 1991).

\section{SCFA and the gut mucosa}

SCFA are the preferred fuel source for colonocytes (Roediger, 1982). Their presence in the colonic lumen stimulates mucosal cell proliferation (Sakata, 1987; Kripke et al. 1988), and increases mucosal blood flow (Kvietys \& Granger, 1981) and intestinal motility 
(Kamath et al. 1988). Colonic infusion of SCFA increases colonic ornithine decarboxylase activity, DNA content and weight in the rat (Reilly et al. 1995). Caecal infusion of SCFA in the rat also increases jejunal DNA content, villous height, surface area and crypt depth (Frankel et al. 1994). It is thought that butyrate contributes to the maintenance of intestinal integrity by suppressing the secretion of urokinase by colonic crypt cells (Gibson et al. 1994). In addition, acetoacetate and 3-hydroxybutyrate stimulate protein synthesis in isolated enterocytes (Higashiguchi et al. 1993).

As instillation of SCFA in the colon has a trophic effect, it seems reasonable to infer that fibre or non-digested carbohydrates which are broken down to SCFA in the colon should also have this effect (Elsen \& Bistrian, 1991). Indeed, pectin and guar have been found to increase mucosal DNA content in the rat colon (Jacobs \& Lupton, 1984).

\section{Fibre or SCFA and experimental disease models}

In a rat model of the short bowel syndrome (Koruda et al. 1986, 1988), enteral pectin or intravenous short chain fatty acids $(a)$ increased mucosal mass; and $(b)$ increased DNA, RNA and protein content.

In rat models of TPN induced colonic atrophy (Kripke et al. 1988; Spaeth et al. 1990; Friedel \& Levine, 1992), colonic SCFA or enteral cellulose (a) increased mucosal height; (b) increased mucosal DNA content; and (c) reduced bacterial translocation.

In experimental colitis (Rolandelli et al. 1988; D’Argenio et al. 1994), enteral pectin or butyrate enemas $(a)$ reduced colonic inflammation.

In a study on experimental colonic anastomosis (Rolandelli et al. 1986a,b), enteral administration of pectin or intracolonic infusion of SCFA enhanced anastomotic healing (bursting strength).

\section{Rationale for the clinical use of SCFA}

It has been proposed that during critical illness the colonic mucosa may be nutritionally deficient and that SCFA administration may enhance function, including water and sodium resorption, and decrease bacterial translocation (Frankel et al. 1994). In addition, low coenzyme A levels have been found in the colonic mucosa of patients with ulcerative colitis which may reduce the efficiency of SCFA oxidation to carbon dioxide and ketone bodies (Ellestad-Sayed et al. 1976). Indeed, decreased faecal concentrations of SCFA have been demonstrated in patients with ulcerative colitis and in those with pouchitis after restorative proctocolectomy (Vernia et al. 1988; Wischmeyer et al. 1993).

It has been suggested that the increased secretion of urokinase (EC 3.4.21.31) observed in inflammatory bowel disease (Elliott et al. 1987; De Bruin et al. 1988) may lead to increased urokinase activity at intercellular junctions and result in increased intestinal permeability (Gibson et al. 1994). Butyrate causes a concentration-dependent suppression of urokinase secretion by colonic crypt cells in vitro (Gibson et al. 1994) and therefore may be beneficial to patients with inflammatory bowel disease by improving intestinal barrier function.

\section{Clinical use of SCFA}

In patients with a defunctioned rectum (Harig et al. 1989; Roediger, 1990; Mortensen et al. 1991) or distal ulcerative colitis (Breuer et al. 1991; Scheppach et al. 1992) intrarectal administration of SCFA increases mucosal blood flow and (a) improves rectal mucosal morphology.

In patients after right hemicolectomy (Scheppach et al. 1989), SCFA administration accelerated intestinal adaptation by $(c)$ stimulating sodium and water absorption in the left hemicolon. 
Experimental and clinical studies therefore show that administration of SCFA has a beneficial effect on colonic inflammation owing to defunction (colonic starvation owing to lack of luminal SCFA) or inflammatory bowel disease (impaired absorption of luminal SCFA) and has potential as a modulator of gut barrier function.

\section{n-3 POLYUNSATURATED FATTY ACIDS}

Polyunsaturated fatty acids are classified into two groups ( $n-3$ and $n-6)$ on the basis of the location of the first double bond counting from the methyl end of the molecule (Simopoulos, 1991). Neither class of fatty acid can be synthesized by humans and must be obtained from the diet. $n-6$ Fatty acids are found in the seeds of most plants whereas $n-3$ fatty acids are found in green leafy vegetables and in fish oils.

\section{Metabolism of polyunsaturated fatty acids}

While both $n-3$ and $n-6$ fatty acids are metabolized to eicosanoids, the prostaglandins and leukotrienes formed have different biological properties (Simopoulos, 1991). When fish oils are ingested, $n-3$ fatty acids replace $n-6$ fatty acids (especially arachidonic acid) in the membranes of platelets, erythrocytes, neutrophils, monocytes and hepatocytes. As a result, there is a decrease in the production of prostaglandin $E_{2}$ metabolites, thromboxane $A_{2}$ and leukotriene $\mathrm{B}_{4}$ with an increased synthesis of prostacyclin $\mathrm{PGI}_{3}$, thromboxane $\mathrm{A}_{3}$ and leukotriene $B_{5}$ (Simopoulos, 1991). The finding of reduced neutrophil and monocyte functions following chronic intake of $n-3$ fatty acids suggests that they may have antiinflammatory properties (Lee et al. 1985).

\section{Eicosanoids and the gut mucosa}

Eicosanoids are mediators of both defensive and inflammatory processes of the gut mucosa (Hawkey \& Rampton, 1985). There is evidence that altered eicosanoid generation is a major pathophysiological feature of inflammatory bowel disease (Hawkey \& Rampton, 1985). Patients who have active colitis have increased concentrations of leukotriene $B_{4}$ and prostaglandin $E_{2}$ in rectal biopsies and dialysates (Sharon et al. 1978; Lauritzen et al. 1984). When a patient goes into remission, the concentration of these eicosanoids falls (Sharon $e t$ al. 1978; Lauritzen et al. 1984).

\section{n-3 Polyunsaturated fatty acids and experimental disease models}

In experimental colitis (Vilaseca et al. 1990; Guarner et al. 1992), dietary supplementation with $n-3$ fatty acids, when compared with $n-6$ fatty acids, $(a)$ reduced severity and duration of colitis in association with reduced luminal release of eicosanoid mediators.

In experimental sepsis, $n-3$ fatty acid supplementation significantly improved intestinal perfusion (Pscheidl et al. 1992) and (d) improved survival (Mascioli et al. 1989).

\section{Rationale for clinical use of $\mathrm{n}-3$ polyunsaturated fatty acids}

Disturbances in colonic mucosal eicosanoid synthesis in ulcerative colitis and evidence that $n-3$ fatty acid dietary supplementation can influence eicosanoid production led to the hypothesis that supplemental fish oil would reduce the inflammatory response in patients with ulcerative colitis (Ross, 1993).

\section{Clinical use of $\mathrm{n}-3$ polyunsaturated fatty acids}

In patients with inflammatory bowel disease initial encouraging reports on uncontrolled trials of fish oils (McCall et al. 1989; Salomon et al. 1990) have been followed by controlled crossover trials (Stenson et al. 1990; Tobin et al. 1990; Aslan \& Triadafilopoulos, 1992). 
Patients with ulcerative colitis given a dietary supplement of fish oils have been shown to increase weight gain, improve colonic histology, reduce disease activity and reduce LTB $_{4}$ in rectal dialysates (Stenson et al. 1990; Tobin et al. 1990; Aslan \& Triadafilopoulos, 1992). There are other studies of fish oil supplementation which showed less promising results (Hawthorne et al. 1990). Ross (1993) has concluded that dietary fish oils provide modest benefits to patients with ulcerative colitis.

In patients with burns (Gottschlich et al. 1990) dietary supplementation with $n-3$ fatty acids or fish oils reduced infectious complications and hospital stay.

Studies describing the use of $n-3$ fatty acids in combination with arginine and nucleotides (Impact) in the critically ill and in patients with gastrointestinal cancer have been discussed under arginine.

\section{NUCLEOTIDES}

Nucleotides are ubiquitous in cells in either monomeric or polymeric form, serving as the structural units for DNA and RNA synthesis and participating (ATP) in intracellular metabolic reactions (van Buren et al. 1994). Nucleotides may be obtained from dietary sources, synthesized de novo or salvaged by intracellular degradation (van Buren et al. 1994).

\section{Metabolism of nucleotides}

Dietary nucleotides are degraded in the intestinal lumen to nucleosides by alkaline phosphatase and nucleotidases, and may be further broken down by nucleosidases to produce purine and pyrimidine bases (Carver, 1994). Enterocytes, however, have a limited capacity to absorb nucleosides or purine and pyrimidine bases. When purines are administered enterally, only adenine is incorporated into the nucleotide pool of the enterocyte and the remainder are degraded to uric acid or allantoin (Rudolph et al. 1990). Although some dietary pyrimidines and bases are absorbed, a considerable amount is catabolized and excreted (Iijima et al . 1993). The major source of nucleotides is, therefore, de novo synthesis from amino acids and sugars in the liver and other organs or salvage by degradation of intracellular polymeric nucleotides.

\section{Nucleotides and the gut mucosa}

The gut has a limited capacity for de novo synthesis of purine and pyrimidine bases and is dependent on the liver for the supply of nucleotides (Savaiano \& Clifford, 1981; LeLeiko et al. 1983). Administration of nucleotides increases gut wall thickness and protein content in weanling mice (Carver et al. 1993) and the rate of intestinal maturation and growth in young rats as assessed by villous height, intestinal mass, RNA, DNA and protein concentrations and activity of brush border enzymes (Uauy et al. 1990). In vitro nucleotide supplementation enhanced the proliferation of a rat small intestinal crypt (IEC-6) cell line but did not affect proliferation and differentiation of a human colon tumour (Caco-2) cell line (He et al. 1993).

\section{Nucleotides and the gut flora}

Nucleotide supplemented commercial milk formulas have been shown to promote the growth of bifidobacteria in the faeces of infants (Gil et al. 1986).

\section{Nucleotides and experimental disease models}

In experimental models of intestinal ischaemia-reperfusion injury, administration of nucleotides, especially adenosine, has been shown to increase intestinal blood flow (Sawmiller \& Chou, 1991) and to attenuate the increase in leukocyte extravasation 
(Grisham et al. 1989; Kaminski \& Proctor, 1992; Asako et al. 1993; Bustamante et al. 1994).

In a lactose induced model of chronic diarrhoea in the weanling rat (Nuñez et al. 1990; Bueno et al. 1994), nucleotide supplementation (a) improved intestinal morphology; $(b)$ increased intestinal protein content; and $(c)$ increased brush border enzyme activity.

In a TPN model of gut atrophy in the rat (Iijima et al. 1993), nucleosides alone or in combination with glutamine $(a)$ improved intestinal morphology; $(b)$ increased intestinal mucosal protein and RNA content; and $(c)$ increased brush border enzyme (maltase) activity.

In protein deficient mice (Adjei et al. 1994; Adjei \& Yamamoto, 1995), intraperitoneal or oral administration of a nucleoside-nucleotide mixture $(a)$ improved intestinal morphology; and $(c)$ reduced bacterial translocation.

\section{Rationale for clinical use of nucleotides}

Enterocytes appear to have a limited ability to synthesize nucleotides de novo (Iijima $e t$ al. 1993). Under normal circumstances, enterocytes depend on the liver and intracellular salvage to provide sufficient monomeric nucleotides to facilitate protein synthesis and cellular proliferation. It has been proposed that these sources may become inadequate, during severe metabolic stress such as trauma, burns and sepsis, to sustain optimal growth of the intestinal mucosa (Uauy et al. 1990). Consequently gut mucosal atrophy may develop with resultant dysfunction of intestinal absorptive and barrier functions (Iijima $e t$ al. 1993; Grimble, 1994).

Nucleotide supplementation can improve intestinal morphometry, biochemical parameters and function in experimental models. It has therefore been suggested that intestinal structure and function is nucleotide limited during critical illness and exogenous nucleotide supplementation may prevent gut derived septic complications (Grimble, 1994).

\section{Clinical use of nucleotides}

In infants of low socioeconomic class in Chile (Brunser et al. 1994), a nucleotide supplemented formula was found to decrease the incidence of diarrhoeal disease. It was suggested that the nucleotides may act by stimulating the growth of bifidobacteria which are known to exert a protective effect against intestinal colonization by enteropathogens.

Studies describing the use of nucleotides in combination with arginine and $n-3$ fatty acids (Impact) in the critically ill and in patients with gastrointestinal cancer have been discussed under arginine. Beneficial effects of nucleotide supplements on gut mucosal structure or function during critical illness remain to be demonstrated (Grimble, 1994).

\section{CONCLUSIONS}

As reviewed above, there is experimental and clinical evidence to support the hypothesis that intestinal barrier dysfunction occurs in critically ill patients and that gut derived bacteria and endotoxin may activate and lead to derangements of the systemic immune system, thus promoting multisystem organ dysfunction. There have been encouraging results from the use of enteral nutrition in experimental models and in patients with trauma or sepsis (Moore et al. 1992). Overall, there is convincing evidence that enteral nutrition is associated with improved immune function and reduced septic complications in severely injured humans when compared to parenteral nutrition (Moore et al. 1992).

The main focus of this review concerns the evaluation of individual nutrients as having a selective action in the maintenance of gut mucosal integrity (selective gut nutrients). However, evidence that such a substrate improves the gut mucosal barrier and increases 
survival does not necessarily imply that restored barrier function and improved survival are causally linked. It may in fact be that the substrates are exerting their beneficial effects by improving nitrogen balance and metabolism or by enhancing immune function (enhanced clearance of translocated bacteria). From the experimental and clinical studies to date, the strongest candidates as selective gut nutrients would appear to be glutamine for the enterocyte and short chain fatty acids for the colonocyte.

While glutamine supplementation of TPN or of elemental diets improves intestinal morphology and barrier function in experimental models, it is important to note that in many of these models complete recovery of intestinal structure and function was produced by a standard oral diet. Therefore a standard oral or polymeric enteral diet is still preferable when clinically feasible and safe. Even when patients are unable to tolerate their full energy needs via the enteral route, enteral administration of $0.6 \mathrm{~g}$ nitrogen $/ \mathrm{kg}$ daily is sufficient to maintain gut integrity and immune function (Moore \& Cerra, 1991). When enteral nutrition is not possible at all, there is experimental and clinical evidence that glutamine supplemented TPN conveys advantages from the gut point of view over standard TPN.

Both short chain fatty acids and $n-3$ polyunsaturated fatty acids have been shown to have modest beneficial effects in patients with ulcerative colitis. Specific arginine supplementation, despite its proven immunological benefit, has no direct mucosal enhancing properties and may be unwise in critical (septic) illness owing to its role as a precursor of nitric oxide synthesis. At present, there is insufficient evidence from clinical studies to suggest that either ornithine or nucleotide supplementation will improve intestinal structure or function. Continued research into these and other novel substrates for the intestine, it is hoped, will lead to improvements in the support of intestinal function during catabolic states and in overall outcome.

\section{REFERENCES}

Adjei, A. A., Ohshiro, Y., Yamauchi, K., Nakasone, Y., Shimada, K., Iwanaga, M. \& Yamamoto, S. (1994). Intraperitoneal administration of nucleoside-nucleotide mixture inhibits endotoxin-induced bacterial translocation in protein-deficient mice. Tohoku Journal of Experimental Medicine 174, 1-10.

Adjei, A. A. \& Yamamoto, S. (1995). A dietary nucleoside-nucleotide mixture inhibits endotoxin-induced bacterial translocation in mice fed protein-free diet. Journal of Nutrition 125, $42-48$.

Alexander, J. W., Boyce, S. T., Babcock, G. F., Gianotti, L., Peck, M. D., Dunn, D. L., Pyles, T., Childress, C. P. \& Ash, S. K. (1990). The process of microbial translocation. Annals of Surgery 212, 496-512.

Alexander, J. W., MacMillan, B. G., Stinnett, J. D., Ogle, C. K., Bozian, R. C., Fischer, J. E., Oakes, J. B., Morris, M. J. \& Krummel, R. (1980). Beneficial effects of aggressive protein feeding in severely burned children. Annals of Surgery 192, 505-517.

Alverdy, J. C., Aoys, B. S. \& Moss, G. S. (1990). Effect of commercially available chemically defined liquid diets on the intestinal microflora and bacterial translocation from the gut. Journal of Parenteral and Enteral Nutrition $14,1-6$.

Ambrose, N. S., Johnson, M., Burdon, D. W. \& Keighley, M. R. B. (1984). Incidence of pathogenic bacteria from mesenteric lymph nodes and ileal serosa during Crohn's disease surgery. British Journal of Surgery 71, 623-625.

Ardawi, M. S. M. (1991). Effect of glutamine-enriched total parenteral nutrition on septic rats. Clinical Science 81, 215-222.

Ardawi, M. S. M. \& Newsholme, E. A. (1985). Fuel utilization in colonocytes of the rat. Biochemical Journal 231, 713-719.

Asako, H., Wolf, R. E. \& Granger, D. N. (1993). Leukocyte adherence in rat mesenteric venules: effects of adenosine and methotrexate. Gastroenterology 104, 31-37.

Aslan, A. \& Triadafilopoulos, G. (1992). Fish oil fatty acid supplementation in active ulcerative colitis: a doubleblind, placebo-controlled crossover study. American Journal of Gastroenterology 87, 432-437.

Babst, R., Hörig, H., Stehle, P., Brand, O., Filgueira, L., Marti, W., Fischer, M., Oberholzer, M., Gudat, F., Fürst, P. \& Heberer, M. (1993). Glutamine peptide-supplemented long-term total parenteral nutrition: effects on intracellular and extracellular amino acid patterns, nitrogen economy, and tissue morphology in growing rats. Journal of Parenteral and Enteral Nutrition 17, 566-574 (erratum 18, 197).

Barber, A. E., Jones, W. G., Minei, J. P., Fahey, T. J., Lowry, S. F. \& Shires, G. T. (1991). Bacterial overgrowth and intestinal atrophy in the etiology of gut barrier failure in the rat. American Journal of Surgery 161, 300-304.

Barber, A. E., Jones, W. G., Minei, J. P., Fahey, T. J., Moldawer, L. L., Rayburn, J. L., Fischer, E., Keogh, C. V., Shires, G. T. \& Lowry, S. F. (1990). Glutamine or fiber supplementation of a defined formula diet : impact 
on bacterial translocation, tissue composition, and response to endotoxin. Journal of Parenteral and Enteral Nutrition 14, 335-343.

Barbul, A. (1986). Arginine: biochemistry, physiology, and therapeutic implications. Journal of Parenteral and Enteral Nutrition 10, 227-238.

Bark, T., Katouli, M., Ljungquist, O., Möllby, R. \& Svenberg, T. (1995). Glutamine supplementation does not prevent bacterial translocation after non-lethal haemorrhage in rats. European Journal of Surgery 161, 3-8.

Baskerville, A., Hambleton, P. \& Benbough, J. E. (1980). Pathologic features of glutaminase toxicity. British Journal of Experimental Pathology 61, 132-138.

Beaulieu, J.-F. \& Calvert, R. (1985). Permissive effect of glutamine on the differentiation of fetal mouse small intestine in organ culture. Differentiation 29, 50-55.

Berg, R. D. (1981). Promotion of the translocation of enteric bacteria from the gastrointestinal tracts of mice by oral treatment with penicillin, clindamycin or metronidazole. Infection and Immunity 33, 854-861.

Berg, R. D. \& Garlington, A. W. (1979). Translocation of certain indigenous bacteria from the gastrointestinal tract to the mesenteric lymph nodes and other organs in a gnotobiotic mouse model. Infection and Immunity 23, 403-411.

Blachier, F., Darcy-Vrillon, B., Sener, A., Duee, P. H. \& Malaisse, W. J. (1991). Arginine metabolism in rat enterocytes. Biochimica et Biophysica Acta 1092, 304-310.

Blair, P., Rowlands, B. J., Lowry, K., Webb, H., Armstrong, P. \& Smilie, J. (1991). Selective decontamination of the digestive tract: a stratified, randomized, prospective study in a mixed intensive care unit. Surgery 110 , 303-310.

Border, J. R., Hassett, J., LaDuca, J., Seibel, R., Steinberg, S., Mills, B., Losi, P. \& Border, D. (1987). The gut origin septic states in blunt multiple trauma (ISS = 40) in the ICU. Annals of Surgery 206, 427-448.

Bower, R. H., Cerra F. B., Bershadsky, B., LiCari, J. J., Hoyt, D. B., Jensen, G. L., van Buren, C. T., Rothkopf, M. M., Daly, J. M. \& Adelsberg, B. R. (1995). Early enteral administration of a formula (Impact) supplemented with arginine, nucleotides, and fish oil in intensive care unit patients: results of a multicenter, prospective, randomized, clinical trial. Critical Care Medicine 23, 436-449.

Breuer, R. I., Buto, S. K., Christ, M. L., Bean, J., Vernia, P., Paoluzi, P., Di Paolo, M. C. \& Caprilli, R. (1991). Rectal irrigation with short chain fatty acids for distal ulcerative colitis: preliminary report. Digestive Diseases and Sciences 36, 185-187.

Brock-Utne, J. G. \& Gaffin, S. L. (1989). Endotoxins and anti-endotoxins (their relevance to the anaesthetist and the intensive care specialist). Anaesthesia and Intensive Care 17, 49-55.

Brunser, O., Espinoza, J., Araya, M., Cruchet, S. \& Gil, A. (1994). Effect of dietary nucleotide supplementation on diarrhoeal disease in infants. Acta Paediatrica 83, 188 191.

Bueno, J., Torres, M., Almendros, A., Carmona, R., Nuñez, M. C., Rios, A. \& Gil, A. (1994). Effect of dietary nucleotides on small intestinal repair after diarrhoea. Histological and ultrastructural changes. Gut 35, $926-933$.

Burke, D. J., Alverdy, J. C., Aoys, E. \& Moss, G. S. (1989). Glutamine-supplemented total parenteral nutrition improves gut immune function. Archives of Surgery 124, 1396-1399.

Burrin, D. G., Shulman, R. J., Langston, C. \& Storm, M. C. (1994). Supplemental alanylglutamine, organ growth and nitrogen metabolism in neonatal pigs fed by total parenteral nutrition. Journal of Parenteral and Enteral Nutrition 18, 313-319.

Busch, J., Hammer, M., Brunkhorst, R. \& Wagner, P. (1988). [Determination of endotoxin in inflammatory rheumatic diseases. Effect of non-steroidal anti-inflammatory drugs on intestinal permeability.] Zeitschrift für Rheumatologie 47, 156-160.

Bustamante, S. A., Sanches, N., Crosier, J., Miranda, D., Colombo, G. \& Miller, M. J. S. (1994). Dietary nucleotides: effects on the gastrointestinal system in swine. Journal of Nutrition 124, 149S-156S.

Byrne, T. A., Morrissey, T. B., Ziegler, T. R., Gatzen, C., Young, L. S. \& Wilmore, D. W. (1992). Growth hormone, glutamine, and fiber enhanced adaptation of remnant bowel following massive intestinal resection. Surgical Forum 43, 151-153.

Carrico, C. J., Meakins, J. L., Marshall, J. C., Fry, D. \& Maier, R. V. (1986). Multiple organ failure syndrome. Archives of Surgery 121, 196-208.

Carver, J., Bustamante, S., Novak, D. \& Barness, L. (1993). Dietary nucleotides may act as growth factors in liver and intestine. FASEB Journal 7, A643.

Carver, J. D. (1994). Dietary nucleotides: cellular immune, intestinal and hepatic system effects. Journal of Nutrition 124, 144S-148S.

Cerra, F. B., Lehman, S., Konstantinides, N., Konstantinides, F., Shronts, E. P. \& Holman, R. (1990). Effect of enteral nutrient on in vitro tests of immune function in ICU patients: a preliminary report. Nutrition 6, 84-87.

Chen, K., Okuma, T., Okamura, K., Torigoe, Y. \& Miyauchi, Y. (1994). Glutamine-supplemented parenteral nutrition improves gut mucosa integrity and function in endotoxemic rats. Journal of Parenteral and Enteral Nutrition 18, 167-171.

Cruz, N., Alvarez, X., Berg, R. D. \& Deitch, E. A. (1994). Bacterial translocation across enterocytes: results of a study of bacterial enterocyte interactions utilizing Caco-2 cells. Shock 1, 67-72.

Cummings, J. H. \& Branch, W. J. (1986). Fermentation and production of short chain fatty acids in the human large intestine. In Dietary fiber: Basic and Clinical Aspects, pp. 131-152 [G. B. Vahouny and D. Kritchevsky, editors]. New York: Plenum Press. 
Cynober, L. (1994). Can arginine and ornithine support gut functions. Gut 35 (Suppl. 1), S42-S45.

Cynober, L., Coudray-Lucas, C., De Bandt, J. P., Guéchot, J., Aussel, C., Salvucci, M. \& Giboudeau, J. (1990). Action of ornithine $\alpha$-ketoglutarate, ornithine hydrochloride and calcium $\alpha$-ketoglutarate on plasma amino acid and hormonal patterns in healthy subjects. Journal of the American College of Nutrition 9, 2-12.

Daly, J. M., Lieberman, M. D., Goldfine, J., Shou, J., Weintraub, F., Rosato, E. F. \& Lavin, P. (1992). Enteral nutrition with supplemental arginine, RNA, and omega-3 fatty acids in patients after operation: immunologic, metabolic, and clinical outcome. Surgery 112, 56-67.

Daly, J. M., Weintraub, F. N., Shou, J., Rosato, E. F. \& Lucia, M. (1995). Enteral nutrition during multimodality therapy in upper gastrointestinal cancer patients. Annals of Surgery 221, 327-338.

D'Argenio, G., Cosenza, V., Sorrentini, I, De Ritis, F., Gatto, A., Cave, M. D., D'Armiento, F. P. \& Mazzacca G. (1994). Butyrate, mesalamine, and factor XIII in experimental colitis in the rat: effects on transglutaminase activity. Gastroenterology 106, 399-404.

De Bruin, P. A. F., Crama-Bohbouth, G., Verspaget, H. W., Verheijen, J. H., Dooijewaard, G., Weterman, I. T. \& Lamers, C. B. H. W. (1988). Plasminogen activators in the intestine of patients with inflammatory bowel disease. Thrombosis and Haemostasis 60, 262-266.

Deitch, E. A. (1990a). Bacterial translocation of the gut flora. Journal of Trauma 30, S184-189.

Deitch, E. A. $(1990 b)$. Intestinal permeability is increased in burn patients shortly after injury. Surgery 107, $411-416$.

Deitch, E. A. (1991). Selective gut nutrition: food for thought or empty calories? Nutrition 7, 10-11.

Deitch, E. A., Ma, W. J., Ma, L., Berg, R. D. \& Specian, R. D. (1990a) Protein malnutrition predisposes to inflammatory-induced gut-origin septic states. Annals of Surgery 211, 560-567.

Deitch, E. A., Morrison, J., Berg, R. \& Specian, R. D. (1990b). Effect of hemorrhagic shock on bacterial translocation, intestinal morphology, and intestinal permeability in conventional and antibiotic-decontaminated rats. Critical Care Medicine 18, 529-536.

Deitch, E. A., Specian, R. D. \& Berg, R. D. (1991). Endotoxin-induced bacterial translocation and mucosal permeability: role of xanthine oxidase, complement activation, and macrophage products. Critical Care Medicine 19, 785-791.

Deitch, E. A., Xu, D., Naruhn, M., Deitch, D. C., Lu, Q. \& Marino, A. A. (1995). Elemental diet and IV-TPNinduced bacterial translocation is associated with loss of intestinal mucosal barrier function against bacteria. Annals of Surgery 221, 299-307.

Deitch, E. A., Xu, D., Qi, L. \& Berg, R. (1993). Elemental diet-induced immune suppression is caused by both bacterial and dietary factors. Journal of Parenteral and Enteral Nutrition 17, 332-336.

Dekker, A. W., Rozenberg-Arska, M., Sixma, J. J. \& Verhoef, J. (1981). Prevention of infection by trimethoprimsulfamethoxazole plus amphotericin B in patients with acute non-lymphocytic leukemia. Annals of Internal Medicine 95, $555-559$.

Eade, M. N. \& Brooke, B. N. (1969). Portal bacteraemia in cases of ulcerative colitis submitted to colectomy. Lancet i, 1008-1009.

Eastwood, G. L. (1977). Small bowel morphology and epithelial proliferation in intravenously alimented rabbits. Surgery 82, 613-620.

Edlund, C., Bergan, T., Josefsson, K., Solberg, R. \& Nord, C. E. (1987). Effect of norfloxacin on human oropharyngeal and colonic microflora and multiple-dose pharmacokinetics. Scandinavian Journal of Infectious Diseases 19, 113-121.

Ellestad-Sayed, J. J., Nelson, R. A., Adson, M. A., Palmer, W. M. \& Soule, E. H. (1976). Pantothenic acid, coenzyme A, and human chronic ulcerative and granulomatous colitis. American Journal of Clinical Nutrition 29, 1333-1338.

Elliott, R., Stephens, R. W. \& Doe, W. F. (1987). Expression of urokinase-type plasminogen activator in the mucosal lesions of inflammatory bowel disease. Journal of Gastroenterology and Hepatology 2, 517-523.

Elsen, R. J. \& Bistrian, B. R. (1991). Recent developments in short-chain fatty acid metabolism. Nutrition 7, 7-10.

Evers, B. M., Izukura, M., Townsend, C. M., Uchida, T. \& Thompson, J. C. (1990). Differential effects of gut hormones on pancreatic and intestinal growth during administration of an elemental diet. Annals of Surgery 211, 630-638.

Fink, M. P. (1991). Gastrointestinal mucosal injury in experimental models of shock, trauma, and sepsis. Critical Care Medicine 19, 627-641.

Flynn, W. J., Gosche, J. R. \& Garrison, R. N. (1992). Intestinal blood flow is restored with glutamine or glucose suffusion after hemorrhage. Journal of Surgical Research 52, 499-504.

Fox, A. D., De Paula, J. A., Kripke, S. A., Palacio, J. C., Berman, J. M., Settle, R. G. \& Rombeau, J. L. (1988 a). Glutamine-supplemented elemental diets reduce endotoxemia in a lethal model of enterocolitis. Surgical Forum $39,46-48$.

Fox, A. D., Kripke, S. A., DePaula, J., Berman, J. M., Settle, R. G. \& Rombeau, J. L. (1988b). Effect of a glutamine-supplemented enteral diet on methotrexate-induced enterocolitis. Journal of Parenteral and Enteral Nutrition 12, 325-331.

Frankel, W. L., Zhang, W., Afonso, J., Klurfeld, D. M., Don, S. H., Laitin, E., Deaton, D., Furth, E. E., Pietra, G. G., Naji, A. \& Rombeau, J. L. (1993). Glutamine enhancement of structure and function in transplanted small intestine in the rat. Journal of Parenteral and Enteral Nutrition 17, 47-55. 
Frankel, W. L., Zhang, W., Singh, A., Klurfeld, D. M., Don, S., Sakata, T., Modlin, I. \& Rombeau, J. L. (1994). Mediation of the trophic effects of short chain fatty acids on the rat jejunum and colon. Gastroenterology 106, 375-380.

Friedel, D. \& Levine, G. M. (1982). Effect of short-chain fatty acids on colonic function and structure. Journal of Parenteral and Enteral Nutrition 16, 1-4.

Gardiner, K. R., Halliday, M. I., Barclay, G. R., Milne, L., Brown, D., Stephens, S., Maxwell, R. J. \& Rowlands, B. J. (1995). Significance of systemic endotoxaemia in inflammatory bowel disease. Gut 36, 897-900.

Gianotti, L., Alexander, J. W., Gennari, R., Pyles, T. \& Babcock, G. F. (1995). Oral glutamine decreases bacterial translocation and improves survival in experimental gut-origin sepsis. Journal of Parenteral and Enteral Nutrition 19, 69-74.

Gianotti, L., Alexander, J. W., Pyles, T. \& Fukushima, R. (1993). Arginine-supplemented diets improve survival in gut-derived sepsis and peritonitis by modulating bacterial clearance. Annals of Surgery 217, $644-654$.

Gibson, P. R., Rosella, O., Rosella, G. \& Young, G. P. (1994). Butyrate is a potent inhibitor of urokinase secretion by normal colonic epithelium in vitro. Gastroenterology $107,410-419$.

Gil, A., Corral, E., Martínez, A. \& Molina, J. A. (1986). Effects of the addition of nucleotides to an adapted milk formula on the microbial pattern of faeces in at term newborn infants. Journal of Clinical Nutrition and Gastroenterology 1, 127-132.

Go, L. L., Healey, P. J., Watkins, S. C., Simmons, R. L. \& Rowe, M. I. (1995). The effect of endotoxin on intestinal mucosal permeability to bacteria in vitro. Archives of Surgery 130, 53-58.

Gonce, S. J., Peck, M. D., Alexander, J. W. \& Miskell, P. W. (1990). Arginine supplementation and its effect on established peritonitis in guinea pigs. Journal of Parenteral and Enteral Nutrition 14, 237-244.

Gottschlich, M. M., Jenkins, M., Warden, G. D., Baumer, T., Havens, P., Snook, J. T. \& Alexander, P. W. (1990). Differential effects of 3 enteral dietary regimens on selected outcome variables in burn patients. Journal of Parenteral and Enteral Nutrition 14, 225-236.

Grant, J. P. \& Snyder, P. J. (1988). Use of L-glutamine in total parenteral nutrition. Journal of Surgical Research 44, 406-513.

Grimble, G. K. (1993). Essential and conditionally-essential nutrients in clinical nutrition. Nutrition Research Reviews 6, 97-119.

Grimble, G. K. (1994). Dietary nucleotides and gut mucosal defence. Gut 35 (Suppl. 1), S46-S51.

Grisham, M. B., Hernandez, L. A. \& Granger, D. N. (1989). Adenosine inhibits ischemia-reperfusion-induced leukocyte adherence and extravasation. American Journal of Physiology 257, H1334-H1339.

Guarner, F., Vilaseca, J. \& Malagelada, J. R. (1992). Dietary manipulation in experimental inflammatory bowel disease. Agents and Actions Special Issue 1, C10-C14.

Guedon, C., Schmitz, J., Lerebours, E., Metayer, J., Audran, E., Hemet, J. \& Colin, R. (1986). Decreased brush border hydrolase activities without gross morphologic changes in human intestinal mucosa after prolonged total parenteral nutrition of adults. Gastroenterology 90, 373-378.

Hammarqvist, F., Wernerman, J., Ali, R. \& Vinnars, E. (1990). Effects of an amino acid solution enriched with either branched-chain amino acids or ornithine-alpha-ketoglutarate on the postoperative intracellular amino acid concentration of skeletal muscle. British Journal of Surgery 77, 214-218.

Harig, J. M., Soergel, K. H., Komorowski, R. A. \& Wood, C. M. (1989). Treatment of diversion colitis with short chain fatty acid irrigation. New England Journal of Medicine 320, $23-28$.

Harvey, L. P., McAnena, O. J., Mehta, B. M. \& Daly, J. M. (1987). Reversibility of elemental liquid dietenhanced methotrexate toxicity by refeeding with chow. Journal of Parenteral and Enteral Nutrition 11, $119-123$.

Hawkey, C. J. \& Rampton, D. S. (1985). Prostaglandins and the gastrointestinal mucosa: are they important in its function, disease, or treatment? Gastroenterology 89, 1162-1188.

Hawthorne, A. B., Daneshment, T. K., Hawkey, C. J., Shaheen, M. Z., Edwards, T. J., Filipowicz, B. L. \& Everitts, J. (1990). A randomized controlled trial of fish oil in ulcerative colitis. Gastroenterology 98, A174.

He, Y., Chu, S-H. W. \& Walker, W. A. (1993). Nucleotide supplements alter proliferation and differentiation of cultured human (Caco-2) and rat (IEC-6) intestinal epithelial cells. Journal of Nutrition 123, 1017-1027.

Helton, S., Smith, R., Hong, R., Rounds, J. \& Wilmore, D. (1991). Are intestinal permeability, bacterial translocation and intestinal atrophy during TPN and enteral feeding related? Journal of Parenteral and Enteral Nutrition 15 (Suppl.), 17.

Higashiguchi, T., Hasselgren, P-O, Wagner, K. \& Fischer, J. E. (1993). Effect of glutamine on protein synthesis in isolated intestinal epithelial cells. Journal of Parenteral and Enteral Nutrition 17, 307-314.

Hoch, R. C., Rodriguez, R., Manning, T., Bishop, M., Mead, P., Shoemaker, W. C. \& Abraham, E. (1993). Effects of accidental trauma on cytokine and endotoxin production. Critical Care Medicine 21, 839-845.

Houdijk, A. P., van Leeuwen, P. A., Boermeester, M. A., van Lambalgen, T., Teerlink, T., Flinkerbusch, E. L., Sauerwein, H. P. \& Wesdorp, R. I. (1994). Glutamine-enriched enteral diet increases splanchnic blood flow in the rat. American Journal of Physiology 267, G1035-1040.

Ijjima, S., Tsujinaka, T., Kido, Y., Hayashida, Y., Ishida, H., Homma, T., Yokoyama, H. \& Mori, T. (1993). Intravenous administration of nucleosides and a nucleotide mixture diminishes intestinal mucosal atrophy induced by total parenteral nutrition. Journal of Parenteral and Enteral Nutrition 17, 265-270.

Illig, K. A., Ryan, C. K., Hardy, D. J., Rhodes, J., Locke, W., Sax, H. C., Schoerb, P. A., Lucas, C. E. \& Fischer, 
J. E. (1992). Total parenteral nutrition-induced changes in gut mucosal function: atrophy alone is not the issue. Surgery 112, 631-637.

Inoue, Y., Grant, J. P. \& Snyder, P. J. (1993a). Effect of glutamine-supplemented intravenous nutrition on survival after Escherichia coli-induced peritonitis. Journal of Parenteral and Enteral Nutrition 17, 41-46.

Inoue, Y., Grant, J. P. \& Snyder, P. J. (1993b). Effect of glutamine-supplemented total parenteral nutrition on recovery of the small intestine after starvation atrophy. Journal of Parenteral and Enteral Nutrition 17, $165-170$.

Jacobs, D. O., Evans, D. A., Mealy, K., O'Dwyer, S. T., Smith, R. J. \& Wilmore, D. W. (1988). Combined effects of glutamine and epidermal growth factor on the rat intestine. Surgery 104, 358-364.

Jacobs, D. O., Evans, D. A., O'Dwyer, S. T., Smith, R. J. \& Wilmore, D. W. (1987). Disparate effects of 5fluorouracil on the ileum and colon of enterally fed rats with protection by dietary glutamine. Surgical Forum 38, 45-46.

Jacobs, D., Evans, D., O'Dwyer, S. T., Smith, R. J. \& Wilmore, D. W. (1988). Trophic effects of glutamineenriched parenteral nutrition on colonic mucosa. Journal of Parenteral and Enteral Nutrition 12 (Suppl. 1), 6.

Jacobs, L. R. \& Lupton, J. R. (1984). Effect of dietary fibers on rat large bowel mucosal growth and cell proliferation. American Journal of Physiology 246: G378-G385.

Jensen, J. C., Schaefer, R., Nwokedi, E., Bevans, D. W., Baker, M. L., Pappas, A. A., Westbrook, K. C. \& Klimberg, V. S. (1994). Prevention of chronic radiation enteropathy by dietary glutamine. Annals of Surgical Oncology 1, 157-163.

Jiang, Z.-M., Wang, L.-J., Qi, Y., Liu, T.-H., Qiu, M.-R., Yang, N.-F. \& Wilmore, D. W. (1993). Comparison of parenteral nutrition supplemented with L-glutamine or glutamine dipeptides. Journal of Parenteral and Enteral Nutrition 17, 134-141.

Kamath, P. S., Phillips, S. F. \& Zinsmeister, A. R. (1988). Short-chain fatty acids stimulate ileal motility in humans. Gastroenterology 95, 1496-1502.

Kaminski, P. M. \& Proctor, K. G. (1992). Extracellular and intracellular actions of adenosine and related compounds in the reperfused rat intestine. Circulation Research 71, 720-731.

Kaneko, H., Ogawa, N. \& Chen, K. (1993). Effects of alanine-glutamine supplemented total parenteral nutrition on protein metabolism and bacterial translocation in septic rats induced by endotoxin. Journal of the Japanese Society of Parenteral and Enteral Nutrition 8, 32-35.

Karatzas, T., Scopa, S., Tsoni, I., Panagopoulos, K., Spiliopolou, I., Moschos, S., Vagianos, K. \& Kalfarentzos, F. (1991). Effect of glutamine on intestinal mucosal integrity and bacterial translocation after abdominal radiation. Clinical Nutrition 10, 199-205.

Kelley, C. J., Ingoldby, C. J. H., Blenkharn, J. I. \& Wood, C. B. (1985). Colonoscopy related endotoxemia. Surgery, Gynecology and Obstetrics 161, 332-334.

Kirk, S. J. \& Barbul, A. (1990). Role of arginine in trauma, sepsis, and immunity. Journal of Parenteral and Enteral Nutrition 14, (Suppl. 5) 226S-229S.

Klimberg, V. S., Nwokedi, E., Hutchins, L. F., Pappas, A. A., Lang, N. P., Broadwater, J. R., Read, R. C. \& Westbrook, K. C. (1992). Glutamine facilitates chemotherapy while reducing toxicity. Journal of Parenteral and Enteral Nutrition 16, 83S-87S.

Klimberg, V. S., Salloum, R. M., Kasper, M., Plumley, D. A., Dolson, D. J., Hautamaki, R. D., Mendenhall, W. R., Bova, F. C., Bland, K. I., Copeland, E. M. \& Souba, W. W. (1990a). Oral glutamine accelerates healing of the small intestine and improves outcome after whole abdominal radiation. Archives of Surgery 125, $1040-1047$.

Klimberg, V. S., Souba, W. W., Dolson, D. J., Salloum, R. M., Hautamaki, R. D., Plumley, D. A., Mendenhall, W. M., Bova, F. J., Khan, S. R., Hackett, R. L., Bland, K. I. \& Copeland, E. M. (1990b). Prophylactic glutamine protects the intestinal mucosa from radiation injury. Cancer 66, 62-68.

Koga, Y., Ikeda, K., Inokuchi, K., Watanabe, H. \& Hashimoto, N. (1975). The digestive tract in total parenteral nutrition. Archives of Surgery 110, 742-745.

Koruda, M. J., Rolandelli, R. H., Bliss, D. Z., Hastings, J., Rombeau, J. L. \& Settle, R. G. (1990). Parenteral nutrition supplemented with short-chain fatty acids : effect on the small-bowel mucosa in normal rats. American Journal of Clinical Nutrition 51, 685-689.

Koruda, M. J., Rolandelli, R. H., Settle, R. G., Saul, S. H. \& Rombeau, J. L. (1986). The effect of a pectinsupplemented elemental diet on intestinal adaptation to massive small bowel resection. Journal of Parenteral and Enteral Nutrition 10, 343-350.

Koruda, M. J., Rolandelli, R. H., Settle, R. G., Zimmaro, D. M. \& Rombeau, J. L. (1988). Effect of parenteral nutrition supplemented with short chain fatty acids on adaptation to massive small bowel resection. Gastroenterology 95, 715-720.

Kripke, S. A., Fox, A. D., Berman, J. M., De Paula, J. A., Rombeau, J. L. \& Settle, G. (1988). Inhibition of TPNassociated colonic atrophy with $\beta$-hydroxybutyrate. Surgical Forum 39, 48-50.

Kubes, P. (1993). Ischemia-reperfusion in feline small intestine: a role for nitric oxide. American Journal of Physiology 264, G143-G149.

Kudsk, K. A. (1994). Gut mucosal nutritional support -- enteral nutrition as primary therapy after multiple system trauma. Gut (Suppl. 1), S52-S54.

Kvietys, P. R. \& Granger, D. N. (1981). Effect of volatile fatty acids on blood flow and oxygen uptake by the dog colon. Gastroenterology 80, 962-969. 
Langkamp-Henken, B., Glezer, J. A. \& Kudsk, K. A. (1992). Immunologic structure and function of the gastrointestinal tract. Nutrition in Clinical Practice 7, 100-108.

Lauritzen, K., Hansen, J., Bytzer, P., Bukhave, K. \& Rask-Madsen, J. (1984). Effects of sulphasalazine and disodium azodisalicylate on colonic PGE2 concentrations determined by equilibrium in vivo dialysis of faeces of patients with ulcerative colitis and healthy controls. Gut 25, 1271-1278.

Lee, T. H., Hoover, R. L., Williams, J. D., Sperling, R. I., Ravalese, J., Spur, B. W., Robinson, D. R., Corey, E. J., Lewis, R. A. \& Austen, K. F. (1985). Effect of dietary enrichment with eicosapentaenoic and docosahexaenoic acids on in vitro neutrophil and monocyte leukotriene generation and neutrophil function. New England Journal of Medicine 312, 1217-1224.

LeLeiko, N. S., Bronstein, A. D., Baliga, B. S. \& Munro, H. N. (1983). De novo purine nucleotide synthesis in the rat small and large intestine: effect of dietary protein and purines. Journal of Pediatric Gastroenterology and Nutrition 2, 313-319.

Lescut, D., Colombel, J. F., Vincent, P., Cortot, A., Fournier, L., Quandalle, P., Vankemmel, M., Triboulet, J. P., Wurtz, A., Paris, J. C. \& Leclerc, H. (1990). Bacterial translocation in colorectal cancers. Gastroenterologie Clinique et Biologique 14, 811-814.

Levine, G. M., Deren, J. J., Steiger, E. \& Zinno, R. (1974). Role of oral intake in maintenance of gut mass and disaccharidase activity. Gastroenterology 67, 975-982.

LeVoyer, T., Cioff, W. G., Pratt, L., Shippee, R., McManus, W. F., Mason, A. D. \& Pruitt, B. A. (1992). Alterations in intestinal permeability after thermal injury. Archives of Surgery 127, 26-30.

Li, J., Langkamp-Henken, B., Suzuki, K. \& Stahlgren, L. H. (1994). Glutamine prevents parenteral nutritioninduced increases in intestinal permeability. Journal of Parenteral and Enteral Nutrition 18, 303-307.

MacBurney, M., Young, L., Ziegler, T. R. \& Wilmore, D. W. (1994). A cost-evaluation of glutaminesupplemented parenteral nutrition in adult bone marrow transplant patients. Journal of the American Dietetic Association 94, 1263-1266.

McCall, T. B., O'Leary, D., Bloomfield, J. \& O'Morain, C. A. (1989). Therapeutic potential of fish oil in the treatment of ulcerative colitis. Alimentary Pharmacology and Therapeutics 3, 415-424.

McCauley, R., Platell, C., Hall, J. \& McCulloch, R. (1991). Effects of glutamine infusion on colonic anastomotic strength in the rat. Journal of Parenteral and Enteral Nutrition 15, 437-439.

Madden, H. P., Breslin, R. J., Wasserkrug, H. L., Efron, G. \& Barbul, A. (1988). Stimulation of T cell immunity by arginine enhances survival in peritonitis. Journal of Surgical Research 44, 658-663.

Marshall, J. C., Christou, N. V., Horn, R. \& Meakins, J. L. (1988). The microbiology of multiple organ failure. The proximal gastrointestinal tract as an occult reservoir of pathogens. Archives of Surgery 123, 309-315.

Mascioli, E. A., Iwasa, Y., Trimbo, S., Leader, L., Bistrian, B. R. \& Blackburn, G. L. (1989). Endotoxin challenge after menhaden oil diet : effects on survival of guinea pigs. American Journal of Clinical Nutrition 49 , 277-282.

Miller, M. J. S., Sadowska-Krowicka, H., Chotinaruemol, S., Kakkis, J. L. \& Clark, D. A. (1993a). Amelioration of chronic ileitis by nitric oxide synthase inhibition. Journal of Pharmacology and Experimental Therapeutics 264, 11-16.

Miller, M. J. S., Zhang, X.-J., Sadowska-Krowicka, H., Chotinaruemol, S., McIntyre, J. A., Clark, D. A. \& Bustamante, S. A. $(1993 b)$. Nitric oxide release in response to gut injury. Scandinavian Journal of Gastroenterology 28, 149-154.

Moore, F. A., Feliciano, D. V., Andrassy, R. J., McArdle, A. H., Booth, F. V. McL., Morgenstein-Wagner, T. B., Kellum, J. M., Welling, R. E. \& Moore, E. E. (1992). Early enteral feeding, compared with parenteral, reduces postoperative septic complications. The results of a meta-analysis. Annals of Surgery 216, 172-183.

Moore, F. A., Moore, E. E., Jones, T. N., McCroskey, B. L. \& Peterson, V. M. (1989). TEN versus TPN following major abdominal trauma-reduced septic morbidity. Journal of Trauma 29, 916-923.

Moore, F. A., Moore, E. E., Poggetti, R., McAnena, O. J., Peterson, V. M., Abernathy, C. M. \& Parsons, P. E. (1991). Gut bacterial translocation via the portal vein: a clinical perspective with major torso trauma. Journal of Trauma 31, 629-638.

Moore, R. S. \& Cerra, F. B. (1991). Sepsis. In Total Parenteral Nutrition, pp. 347-365. [J. E. Fischer, editor]. Boston: Little, Brown.

Mortensen, F. V., Hessov, I., Birke, H., Korsgaard, N. \& Nielsen, H. (1991). Microcirculatory and trophic effects of short chain fatty acids in the human rectum after Hartmann's procedure. British Journal of Surgery $\mathbf{7 8}$, 1208-1211.

Murphy, M. S., Eastham, E. J., Nelson, R., Pearson, A. D. \& Laker, M. F. (1989). Intestinal permeability in Crohn's discase. Archives of Disease in Childhood 64, 321-325.

Neilly, P. J. D., Anderson, N. H., Kirk, S. J., Gardiner, K. R., Halliday, M. I. \& Rowlands, B. J. (1993). LArginine exacerbates the inflammatory response in experimental inflammatory bowel disease. Gut 34 , S60.

Neilly, P. J. D., Kirk, S. J., Gardiner, K. R., Anderson, N. H. \& Rowlands, B. J. (1995). Manipulation of the Larginine-nitric oxide pathway in experimental colitis. British Journal of Surgery 82, $1188-1191$.

Nuñez, M. C., Ayudarte, M. V., Morales, D., Suarez, M. D. \& Gil, A. (1990). Effect of dietary nucleotides on intestinal repair in rats with experimental chronic diarrhea. Journal of Parenteral and Enteral Nutrition 14, 598-604.

O'Dwyer, S. T., Michie, H. R., Ziegler, T. R., Revhaug, A., Smith, R. J. \& Wilmore, D. W. (1988). A single dose of endotoxin increases intestinal permeability in healthy humans. Archives of Surgery 123, 1459-1464. 
O'Dwyer, S. T., Scott, T., Smith, R. J. \& Wilmore, D. W. (1987). 5-fluorouracil toxicity on small intestinal mucosa but not white blood cells is decreased by glutamine. Clinical Research 35, 369a.

O'Dwyer, S. T., Smith, R. J., Hwang, T. L. \& Wilmore, D. W. (1989). Maintenance of small bowel mucosa with glutamine-enriched parenteral nutrition. Journal of Parenteral and Enteral Nutrition 13, 579-585.

Okabe, S., Honda, K., Takeuchi, K. \& Takagi, K. (1975). Inhibitory effect of L-glutamine on gastric irritation and back diffusion of gastric acid in response to aspirin in the rat. American Journal of Digestive Diseases 20, 626-631.

Parrilli, G., Iaffaioli, V., Capuano, G., Budillon, G. \& Bianco, R. (1982). Changes in intestinal permeability to lactulose induced by cytotoxic chemotherapy. Cancer Treatment Reports 66, 1435-1436.

Petros, A., Bennett, D. \& Vallance, P. (1991). Effect of nitric oxide synthase inhibitors on hypotension in patients with septic shock. Lancet 338, 1557-1558.

Pironi, L., Miglioni, M., Ruggeri, E., Levorato, M., Dallasa, M. A., Corbelli, C., Nibali, M. G. \& Barbara, L. (1990). Relationship between intestinal permeability to 51Cr-EDTA and inflammatory activity in asymptomatic patients with Crohn's disease. Digestive Diseases and Sciences 35, 582-588.

Platell, C., McCauley, R., McCulloch, R. \& Hall, J. (1993). The influence of parenteral glutamine and branched chain amino acids on total parenteral nutrition-induced atrophy of the gut. Journal of Parenteral and Enteral Nutrition 17, 348-354.

Pscheidl, E. M., Wan, J. M., Blackburn, G. L., Bistrian, B. R. \& Istfan, N. W. (1992). Influence of $\omega-3$ fatty acids on splanchnic blood flow and lactate metabolism in an endotoxemic rat model. Metabolism 41, 698-705.

Reilly, K. J., Adamson, W. T., Bain, A. M. \& Rombeau, J. L. (1995). Short chain fatty acids (SCFA) induce colonotrophism by stimulating ornithine decarboxylase (ODC) activity. Journal of Parenteral and Enteral Nutrition 19, 24 S.

Rémésy, C., Demigné, C. \& Chartier, F. (1980). Origin and utilization of volatile fatty acids in the rat. Reproduction, Nutrition, Développement 20, 1339-1349.

Roediger, W. E. W. (1982). Utilization of nutrients by isolated epithelial cells of the rat colon. Gastroenterology 83, 424-429.

Roediger, W. E. W. (1990). The starved colon - diminished mucosal nutrition, diminished absorption, and colitis. Diseases of the Colon and Rectum 33, 858-862.

Rolandelli, R., Koruda, M. J., Settle, R. G. \& Rombeau, J. L. (1986a). Effects of intraluminal infusion of short chain fatty acids on the healing of colonic anastomoses in the rat. Surgery 100, 198-204.

Rolandelli, R. H., Koruda, M. J., Settle, R. G. \& Rombeau, J. L. (1986b). The effect of enteral feedings supplemented with pectin on the healing of colonic anastomoses in the rat. Surgery 99, 703-707.

Rolandelli, R. H., Saul, S. H., Settle, R. G., Jacobs, D. O., Trerotola, S. O. \& Rombeau, J. L. (1988). Comparison of parenteral nutrition and enteral feeding with pectin in experimental colitis in the rat. American Journal of Clinical Nutrition 47, 715-721.

Ross, E. (1993). The role of marine fish oils in the treatment of ulcerative colitis. Nutrition Reviews 51, 47-49.

Roumen, R. M. H., Hendriks, T., Wevers, R. A. \& Goris, R. J. A. (1993). Intestinal permeability after severe trauma and hemorrhagic shock is increased without relation to septic complications. Archives of Surgery 128 , 453-457.

Rozenberg-Arska, M. \& Dekker, A. W. (1987). Ciprofloxacin for infection prevention in patients with acute leukaemia. Pharmaceutische Weekblad (Scientific Edition) 9 (Suppl.) 45-7.

Rudolph, F. B., Kulkarni, A. D., Fanslow, W. C., Pizzini, R. P., Kumar, S. \& Van Buren, C. T. (1990). Role of RNA as a dietary source of pyrimidines and purines in immune function. Nutrition 6, 45-52.

Rush, B. F., Sori, A. J., Murphy, T. F., Smith, S., Flanagan, J. J. \& Machiedo, G. W. (1988). Endotoxemia and bacteremia during hemorrhagic shock. The link between trauma and sepsis? Annals of Surgery 207, $549-554$.

Saadia, R., Schein, M., McFarlane, C. \& Boffard, K. D. (1990). Gut barrier function and the surgeon. British Journal of Surgery 77, 487-492.

Saito, H., Trocki, O., Alexander, J. W., Kopcha, R., Heyd, T. \& Joffe, S. N. (1987a). The effect of route of nutrient administration on the nutritional state, catabolic hormone secretion, and gut mucosal integrity after burn injury. Journal of Parenteral and Enteral Nutrition 11, 1-7.

Saito, H., Trocki, O., Wang, S.-L., Gonce, S. J., Joffe, S. N. \& Alexander, J. W. (1987b). Metabolic and immune effects of dietary arginine supplementation after burn. Archives of Surgery 122, 784-789.

Sakata, T. (1987). Stimulatory effect of short chain fatty acids on epithelial cell proliferation in the rat intestine. A possible explanation for trophic effects of fermentable fibre, gut microbes and luminal trophic factors. British Journal of Nutrition 58, 95-103.

Salloum, R. M., Copeland, E. M. \& Souba, W. W. (1991). Brush border transport of glutamine and other substrates during sepsis and endotoxemia. Annals of Surgery 213, 401-410.

Salloum, R. M., Souba, W. W., Klimberg, V. S., Plumley, D. A., Dolson, D. J., Bland, K. I. \& Copeland, E. M. (1989). Glutamine is superior to glutamate in supporting gut metabolism, stimulating intestinal glutaminase activity, and preventing bacterial translocation. Surgical Forum 40, 6-8.

Salomon, P., Kornbluth, A. A. \& Janowitz, H. D. (1990). Treatment of ulcerative colitis with fish oil n-3 fatty acid: an open trial. Journal of Clinical Gastroenterology 12, 157-161.

Sartor, R. B. (1990). Role of intestinal microflora in initiation and perpetuation of inflammatory bowel disease. Canadian Journal of Gastroenterology 4, 271-277. 
Savaiano, D. A. \& Clifford, A. J. (1981). Adenine, the precursor of nucleic acids in intestinal cells unable to synthesize purines de novo. Journal of Nutrition 111, 1816-1822.

Sawmiller, D. R. \& Chou, C. C. (1991). Adenosine is a vasodilator in the intestinal mucosa. American Journal of Physiology 261, G9-G15.

Scheppach, W. (1994). Effects of short chain fatty acids on gut morphology and function. Gut 35 (Suppl. 1), S35-S38.

Scheppach, W., Pomare, E. W., Elia, M. \& Cummings, J. H. (1991). The contribution of the large intestine to blood acetate in man. Clinical Science 80, 177-182.

Scheppach, W., Sachs, M., Bartram, P. \& Kasper, H. (1989). Faecal short-chain fatty acids after colonic surgery. European Journal of Clinical Nutrition 43, 21-25.

Scheppach, W., Sommer, H., Kirchner, T., Paganelli, G.-M., Bartram, P., Christl, S., Richter, F., Dusel, G. \& Kasper, H. (1992). Effect of butyrate enemas on the colonic mucosa in distal ulcerative colitis. Gastroenterology $103,51-56$.

Schloerb, P. R. \& Amare, M. (1993). Total parenteral nutrition with glutamine in bone marrow transplantation and other clinical applications (a randomized, double-blind study). Journal of Parenteral and Enteral Nutrition 17, 407-413.

Scott, T. E. \& Moellman, J. R. (1992). Intravenous glutamine fails to improve gut morphology after radiation injury. Journal of Parenteral and Enteral Nutrition 16, $440-444$.

Sedman, P. C., MacFie, J., Sagar, P., Mitchell, C. J., May, J., Mancey-Jones, B. \& Johnstone, D. (1994). The prevalence of gut translocation in humans. Gastroenterology 107, 643-649.

Sedman, P. C., May, J., Brooks, S. G., Sagar, P., Johnson, D., Tring, I., Mitchell, C. J. \& MacFie, J. (1993). Total parenteral nutrition does not predispose to gut translocation in man. Gut 34, S64.

Sharon, P., Ligumsky, M., Rachmilewitz, D. \& Zor, U. (1978). Role of prostaglandins in ulcerative colitis. Enhanced production during active disease and inhibition by sulfasalazine. Gastroenterology 75, 638-640.

Shou, J., Lieberman, M. D., Hofmann, K., Leon, P., Redmond, H. P., Davies, H. \& Daly, J. M. (1991). Dietary manipulation of methotrexate-induced enterocolitis. Journal of Parenteral and Enteral Nutrition 15, $307-312$.

Simopoulos, A. P. (1991). Omega-3 fatty acids in health and disease and in growth and development. Review. American Journal of Clinical Nutrition 54, 438-463.

Sitren, H. S., Bryant, M. \& Ellis, L. M. (1992). Species differences in TPN-induced intestinal villus atrophy. Journal of Parenteral and Enteral Nutrition 16, $30 \mathrm{~S}$.

Smith, R. J. \& Wilmore, D. W. (1990). Glutamine nutrition and requirements. Journal of Parenteral and Enteral Nutrition 14 (Suppl. 4), 94S-99S.

Souba, W. W. \& Copeland, E. M. (1992). Cytokine modulation of sodium-dependent glutamine transport across the brush border membrane of monolayers of human intestinal Caco-2 cells. Annals of Surgery 215, 536-545.

Souba, W. W., Herskowitz, K., Austgen, T. R., Chen, M. K. \& Salloum, R. M. (1990a). Glutamine nutrition: theoretical considerations and therapeutic impact. Journal of Parenteral and Enteral Nutrition 14, 237-243S.

Souba, W. W., Herskowitz, K., Klimberg, V. S., Salloum, R. M., Plumley, D. A., Flynn, T. C. \& Copeland, E. M. $(1990 \mathrm{~b})$. The effects of sepsis and endotoxemia on gut glutamine metabolism. Annals of Surgery 211, 543-551.

Souba, W. W., Klimberg, V.S., Hautamaki, R. D., Mendenhall, W. H., Bova, F. C., Howard, R. J., Bland, K. I. \& Copeland, E. M. $(1990 \mathrm{c})$. Oral glutamine reduces bacterial translocation following abdominal radiation. Journal of Surgical Research 48, 1-5.

Souba, W. W., Smith, R. J. \& Wilmore, D. W. (1985). Glutamine metabolism by the intestinal tract. Journal of Parenteral and Enteral Nutrition 9, 608-617.

Spaeth, G., Berg, R. D., Specian, R. \& Deitch, E. A. (1990). Food without fiber promotes bacterial translocation from the gut. Surgery 108, 240-247.

Spaeth, G., Gottwald, T., Haas, W. \& Holmer, M. (1993). Glutamine peptide does not improve gut barrier function and mucosal immunity in total parenteral nutrition. Journal of Parenteral and Enteral Nutrition 17, 317-323.

Spaeth, G., Gottwald, T., Specian, R. D., Mainous, M. R., Berg, R. D. \& Deitch, E. A. (1994). Secretory immunoglobulin A, intestinal mucin, and mucosal permeability in nutritionally induced bacterial translocation in rats. Annals of Surgery 220, 798-808.

Stehle, P., Zander, J., Mertes, N., Albers, S., Puchstein, Ch., Lawin, P. \& Fürst, P. (1989). Effect of parenteral glutamine peptide supplements on muscle glutamine loss and nitrogen balance after major surgery. Lancet $\mathbf{i}$, 231-233.

Stenson, W. F., Cort, D., Beeken, W., Rodgers, J. \& Burakoff, R. (1990). A trial of fish oil supplemental diet in ulcerative colitis. Gastroenterology 98, A475.

Tamada, H., Nezu, R., Imamura, I., Matsuo, Y., Takagi, Y., Kamata, S. \& Okada, A. (1992). The dipeptide alanyl-glutamine prevents intestinal mucosal atrophy in parenterally fed rats. Journal of Parenteral and Enteral Nutrition 16, 110-116.

Tancrede, C. H. \& Andremont, A. O. (1985). Bacterial translocation and gram-negative bacteremia in patients with hematological malignancies. Journal of Infectious Diseases 152, 99-103.

Tobin, A., Suzuki, Y. \& O'Morain, C. (1990). A controlled double blind crossover study in ulcerative colitis. Gastroenterology 98, A207.

Tran, D. D., Cuesta, M. A., van Leeuwen, P. A. M., Nauta, J. J. P. \& Wesdorp, R. I. C. (1993). Risk factors for multiple organ system failure and death in critically injured patients. Surgery 114, $21-30$. 
Travis, S. \& Menzies, I. (1992). Intestinal permeability: functional assessment and significance. Review. Clinical Science 82, 471-488.

Tremel, H., Kienle, B., Weilemann, L. S., Stehle, P. \& Furst, P. (1994). Glutamine dipeptide-supplemented parenteral nutrition maintains intestinal function in the critically ill. Gastroenterology 107, 1595-1601.

Uauy, R., Stringel, G., Thomas, R. \& Quan, R. (1990). Effect of dietary nucleosides on growth and maturation of the developing gut in the rat. Journal of Pediatric Gastroenterology and Nutrition 10, 497-503.

van Buren, C. T., Kulkarni, A. D. \& Rudolph, F. B. (1994). The role of nucleotides in adult nutrition. Journal of Nutrition 124, 160S-164S.

van der Hulst, R. R. W. J., van Kreel, B. K., von Meyenfeldt, M. F., Brummer, R.-J. M., Arends, J.-W., Deutz, N. E. P. \& Soeters, P. B. (1993). Glutamine and the preservation of gut integrity. Lancet 341, $1363-1365$.

van Leeuwen, P. A. M., Boermeester, M. A., Houdijk, A. P. J., Ferwerda, Ch. C., Cuesta, M. A., Meyer, S. \& Wesdorp, R. I. C. (1994). Clinical significance of translocation. Gut 35 (Suppl. 1), S28-S34.

van Zaanen, H. C. T., van der Lelie, H., Timmer, J. G., Furst, P. \& Sauerwein, H. P. (1994). Parenteral glutamine dipeptide supplementation does not ameliorate chemotherapy-induced toxicity. Cancer 74, 2879-2884.

Vaubourdolle, M., Jardel, A., Coudray-Lucas, C., Ekindjian, O. G., Agneray, J. \& Cynober, L. (1989). Fate of enterally administered ornithine in healthy animals: interactions with alpha-ketoglutarate. Nutrition 5, $183-187$.

Vernia, P., Gnaedinger, A., Hauck, W. \& Breuer, R. I. (1988). Organic anions and the diarrhea of inflammatory bowel disease. Digestive Diseases and Sciences 33, 1353-1358.

Vilaseca, J., Salas, A., Guarner, F., Rodríguez, R., Martínez, M. \& Malagelada, J.-R. (1990). Dietary fish oil reduces progression of chronic inflammatory lesions in a rat model of granulomatous colitis. Gut 31, 539-544.

Wang, X., Jacobs, D. O., O'Dwyer, S. T., Smith, R. J. \& Wilmore, D. W. (1988). Glutamine-enriched parenteral nutrition prevents mucosal atrophy following massive small bowel resection. Surgical Forum 39, $44-46$.

Wellmann, W., Fink, P. C., Benner, F. \& Schmidt, F. W. (1986). Endotoxaemia in active Crohn's disease. Treatment with whole gut irrigation and 5-aminosalicylic acid. Gut 27, 814-820.

Wells, C. L., Jechorek, R. P. \& Erlandsen, S. L. (1990). Evidence for the translocation of Enterococcus faecalis across the mouse intestinal tract. Journal of Infectious Diseases 162, 82-90.

Wells, C. L., Jechorek, R. P., Olmsted, S. B. \& Erlandsen, S. L. (1993). Effect of LPS on epithelial integrity and bacterial uptake in the polarized human enterocyte-like cell line Caco-2. Circulation Shock 40, 276-288.

Wilmore, D. W. (1994). Glutamine and the gut. Gastroenterology 107, 1885-1886.

Wilmore, D. W., Smith, R. J., O'Dwyer, S. T., Jacobs, D. O., Ziegler, T. R. \& Wang, X.-D. (1988). The gut: a central organ after surgical stress. Surgery 104, 917-923.

Windmueller, H. (1982). Glutamine utilization by the small intestine. Advances in Enzymology 53, 202-237.

Wischmeyer, P., Pemberton, J. H. \& Phillips, S. F. (1993). Chronic pouchitis after ileal pouch-anal anastomosis: responses to butyrate and glutamine suppositories in a pilot study. Mayo Clinic Proceedings 68, 978-981.

Wusteman, M., Tate, H., Weaver, L., Austin, S., Neale, G. \& Elia, M. (1995). The effect of enteral glutamine deprivation and supplementation on the structure of rat small-intestine mucosa during a systemic injury response. Journal of Parenteral and Enteral Nutrition 19, 22-27.

Yoshida, S., Leskiw, M. J., Schluter, M. D., Bush, K. T., Nagele, R. G., Lanza-Jacoby, S. \& Stein, T. P. (1992). Effect of total parenteral nutrition, systemic sepsis, and glutamine on gut mucosa in rats. American Journal of Physiology 263, E368-373.

Zaloga, G. P., Knowles, R., Black, K. W. \& Prielipp, R. (1991). Total parenteral nutrition increases mortality after hemorrhage. Critical Care Medicine 19, 54-59.

Zhang, W., Frankel, W. L., Bain, A., Choi, D., Klurfeld, D. M. \& Rombeau, J. L. (1995). Glutamine reduces bacterial translocation after small bowel transplantation in cyclosporine-treated rats. Journal of Surgical Research 58, $159-164$.

Ziegler, T. R., Smith, R. J., O'Dwyer, S. T., Demling, R. H. \& Wilmore, D. W. (1988). Increased intestinal permeability associated with infection in burn patients. Archives of Surgery 123, 1313-1319.

Ziegler, T. R., Young, L. S., Benfell, K., Scheltinga, M., Hortos, K., Bye, R., Morrow, F. D., Jacobs, D. O., Smith, R. J., Antin, J. H. \& Wilmore, D. W. (1992). Clinical and metabolic efficacy of glutamine-supplemented total parenteral nutrition after bone marrow transplantation. A randomized, double-blind, controlled study. Annals of Internal Medicine 116, 821-828. 